\title{
Molecular Phylogeny of Extant Holothuroidea (Echinodermata)
}

Allison K. Miller 1 , Alexander M. Kerr 1 , Gustav Paulay, , Mike Reich $_{3,4,5}$, Nerida G. Wilson 6,7 , Jose I. Carvajal 6,7 , and Greg W. Rouse 7

${ }_{1}$ University of Guam, Marine Laboratory, UOG Station Mangilao, Guam 96923, USA

${ }_{2}$ Florida Museum of Natural History, University of Florida, Gainesville, FL, USA

${ }_{3}$ Bavarian State Collection of Palaeontology and Geology, Richard-Wagner-Str. 10, 80333

München, Germany,

${ }_{4}$ Ludwig-Maximilians-Universität (LMU) München, Department of Earth and Environmental

Sciences, Richard-Wagner-Str. 10, 80333 München, Germany

${ }_{5}$ GeoBio Center ${ }^{\text {LMU }}$, Richard-Wagner-Str. 10, 80333 München, Germany

${ }_{6}$ Western Australian Museum, Locked Bag 49, Welshpool DC, WA 6986, Australia

${ }_{7}$ Scripps Institution of Oceanography, University of California, San Diego, La Jolla, California 92037, USA

Corresponding authors: Allison K. Miller, a33miller@gmail.com and Greg W. Rouse, grouse@ ucsd.edu

(C) 2016. This manuscript version is made available under the Elsevier user license 


\begin{abstract}
:
Sea cucumbers (Holothuroidea) are a morphologically diverse, ecologically important, and economically valued clade of echinoderms; however, the understanding of the overall systematics of the group remains controversial. Here, we present a phylogeny of extant Holothuroidea assessed with maximum parsimony, maximum likelihood, and Bayesian approaches using approximately $4.3 \mathrm{~kb}$ of $\mathrm{mt}-(\mathrm{COI}, 16 \mathrm{~S}, 12 \mathrm{~S})$ and nDNA (H3, 18S, 28S) sequences from 82 holothuroid terminals representing 23 of the 27 widely-accepted familyranked taxa. Currently five holothuroid taxa of ordinal rank are accepted. We find that three of the five orders are non-monophyletic, and we revise the taxonomy of the groups accordingly. Apodida is sister to the rest of Holothuroidea, here considered Actinopoda. Within Actinopoda, Elasipodida in part is sister to the remaining Actinopoda. This latter clade, comprising holothuroids with respiratory trees, is now called Pneumonophora. The traditional Aspidochirotida is paraphyletic, with representatives from three orders (Molpadida, Dendrochirotida, and Elasipodida in part) nested within. Therefore, we discontinue the use of Aspidochirotida and instead erect Holothuriida as the sister group to the remaining Pneumonophora, here termed Neoholothuriida. We found four well-supported major clades in Neoholothuriida: Dendrochirotida, Synallactida, Molpadida and a new taxon, Persiculida. The mapping of traditionally-used morphological characters in holothuroid systematics onto the phylogeny revealed marked homoplasy in most characters demonstrating that further taxonomic revision of Holothuroidea is required. Two time-tree analyses, one based on calibrations for uncontroversial crown group dates for Eleutherozoa, Echinozoa and Holothuroidea and another using these calibrations plus four more from within Holothuroidea, showed major discrepancies, suggesting that fossils of Holothuroidea may need reassessment in terms of placing these forms with existing crown clades.
\end{abstract}

Keywords:

Holothuroidea; sea cucumbers; phylogeny; nomenclature; molecular clock; transformations 


\subsection{Introduction}

Holothuroids, or sea cucumbers, are a diverse and economically important group of echinoderms. Well known for their many bizarre features (e.g., evisceration [García-Arrarás and Greenberg, 2001], anal suspension feeding [Jaeckle and Strathmann, 2013], and body wall shedding [Kropp, 1982]), the 1693 accepted extant species (Paulay and Hansson, 2013) show a varied range of forms (Fig. 1). Adult sizes range from $2 \mathrm{~mm}$ to $>3 \mathrm{~m}$, and they can be found in almost every benthic marine environment, including polar regions (O’Loughlin et al., 2010) and the deepest oceanic trench (Gallo et al., 2015). Highest species diversity occurs in the shallow waters of the Indo-West Pacific where hundreds of species are recognized (Paulay and Hansson, 2013). Unsurprisingly, these areas are the most heavily targeted by the bêche-de-mer, or trepang, fisheries. Dried, cooked, pickled, or raw holothuroids are commonly consumed as culinary delicacies, especially in Asia (Conand, 1989), where high demand has led to global exploitation and skyrocketing prices. Apostichopus japonicus, for example, sells for up to US\$2,950 per $\mathrm{kg}$ (US\$1,338 per lb) in Hong Kong retail markets (Purcell et al., 2012). At present, there are seven species listed as endangered on the IUCN Red List, and nine listed as vulnerable (accessed 15 Feb 2017).

Despite their diversity, abundance, and economic importance, our understanding of the higher-level relationships within the group remains limited. Multiple incongruences between morphology based taxonomic systems (e.g., Becher, 1909; Kerr and Kim, 2001; Ludwig, 18891892; Östergren, 1907; Pawson and Fell, 1965) and limited molecular systematic studies to date (e.g., Arndt et al., 1996; Kerr and Kim, 1999; Lacey et al., 2005; Littlewood et al., 1997), leave many questions regarding holothuroid evolution unanswered. To provide a more in-depth understanding of the higher-level phylogenetic relationships of extant Holothuroidea, we sequenced DNA fragments of six nuclear and mitochondrial genes from 82 holothuroid terminals, representing 23 of the 27 currently accepted family-ranked taxa. Maximum likelihood, Bayesian inference, and maximum parsimony phylogenetic analyses were applied to concatenated gene datasets. Based on these results, we propose a revised taxonomy for the major holothuroid clades. We then mapped four morphological traits onto our molecular phylogenetic results to assess their transformations and utility in systematics. We also conducted time-tree analyses for the group with holothuroid fossils. 


\subsubsection{Taxonomic history}

Various authors have presented reviews of the systems and phylogenies produced by holothuroid taxonomists in the 1800's and early 1900's (Kerr and Kim, 2001; Ludwig, 18891892; Samyn, 2003; Smirnov, 2012). To summarize, many early holothuroid taxonomists (Haeckel, 1896; Ludwig, 1891; Perrier, 1902; Semper, 1867-8), used only a few selected morphological characters (e.g., respiratory trees and tubefeet) to support their phylogenetic theories of the group (Fig. 2A-D). It was only in the beginning of the 1900's that workers (e.g. Becher, 1909; Cuénot, 1948; MacBride, 1906; Östergren, 1907) began to incorporate multiple morphological characters (e.g., tentacle morphology, tentacle ampullae, respiratory trees, and muscle bands) into their systems (Fig. 2E-H).

Until recently, the most widely-used classification of Holothuroidea was that of Pawson and Fell (1965) (Fig. 2I). This was primarily based on tentacle morphology, body morphology, and, partially, on the shape of the calcareous ring. Following several earlier authors (Deichmann, 1930; Haeckel, 1896; Ludwig, 1889-1892), Pawson and Fell (1965) used five previously erected ordinal-ranked taxa (Apodida, Elasipodida, Aspidochirotida, Molpadida, and Dendrochirotida), and also named a sixth, Dactylochirotida, based on the group's digitiform to digitate tentacles and plated (imbricate) body walls (i.e., a “test”). Pawson and Fell (1965) incorporated Dactylochirotida with Dendrochirotida as a new subclass, Dendrochirotacea, which they recognized along with the subclass Aspidochirotacea (Elasipodida + Aspidochirotida) and Apodacea (Molpadida + Apodida) (Fig. 2I). Their text supported the views of past taxonomists (e.g., Théel, 1886) and that of later paleontologists (e.g., Boczarowski, 1997; Boczarowski, 2001; Haude, 1995, 2002; Jell, 2010) who postulated that the earliest holothuroid ancestors resembled some extant Dendrochirotida.

Despite the wide use of Pawson and Fell's (1965) taxonomic system, various authors offered alternate views about the relationships of its higher levels. For instance, Hansen (1975) dismissed Aspidochirotacea, and while Haude (1992) produced a classification (Fig. 2J) that largely matched that of Pawson and Fell's (1965), he questioned grouping Molpadida with Apodida as Apodacea, and suggested that Molpadida might belong in Dendrochirotacea. Haude (1992), as with other authors, (Cuénot, 1891; Huxley, 1878; Östergren, 1907; Seilacher, 1961; Semon, 1888; Semper, 1867-8), did not agree with Pawson and Fell's (1965) hypothesis of a dendrochirote-like ancestor for Holothuroidea, and instead proposed an apodan-like ancestor. 
Dactylochirotida is now generally considered as part of Dendrochirotida (Paulay and Hansson, 2013; Smirnov, 2012).

While higher-level relationships of holothuroids have been verbally discussed at length, few phylogenetic studies have addressed their evolution. Arndt et al. (1996) and Littlewood et al. (1997) (later interpreted by Smith, 1997) provided limited initial molecular phylogenies of seven and four genera (Fig. 2K). Kerr and Kim (2001) presented the first broad phylogenetic analysis based on morphological data from all recognized families (Fig. 2L). Lacey et al. (2005) published the only broad molecular phylogeny to date based on $18 \mathrm{~S}$ sequence data from 15 genera representing four of the currently recognized orders (Fig. 2M). All of these studies supported the hypothesis of Apodida as sister to Elasipodida + remaining holothuroids. Reich (2010a) added fossil evidence to previous morphological and molecular evidence and agreed with this hypothesis, postulating a close relationship of Elasipodida to Apodida owing to the presence of wheel-like ossicles and statocysts (Fig. 2N).

Smirnov (2012) published the most recent broad holothuroid taxonomic system (Fig. 2O) after considering the views of Becher (1909,) Kerr and Kim (2001), and the results from previously published (Lacey et al., 2005; Smith, 1997) and unpublished (Solís-Marín, 2003) molecular phylogenetic and paleontological findings (Reich, 2010a; Reich, 2010c). Partially following Becher's (1909) phylogeny, Smirnov (2012) proposed that one group (Synaptacea) include holothuroids with wheel-shaped ossicles and without respiratory trees, and that a second group (Holothuriacea + Elpidiacea) include holothuroids with both respiratory trees and secondarily-lost respiratory trees. He also erected Mesothuriidae to separate Mesothuria and Zygothuria from Synallactidae, following earlier suggestions of similarities of this group with Holothuriidae (Becher, 1909; Sluiter, 1901a), and raised four subfamilies to family status within the Dendrochirotida.

\subsection{Material and methods}

\subsubsection{Sample acquisition}

Targeted holothuroids were collected by SCUBA diving, snorkeling, dredging, trawling, submersible, or remote operated vehicle (ROV) from diverse localities (Table 1). Holothuroid representatives from Pawson and Fell's (1965) six orders and from 23 of the 27 widely-accepted extant holothuroid families (Paulay and Hansson, 2013) were included. Most are deposited at 
either the Scripps Institution of Oceanography Benthic Invertebrate Collection (SIO-BIC), or the Florida Museum of Natural History Invertebrate Zoology Collection (UF). The rest are deposited at the Museum Victoria Marine Invertebrates Collection (NMV), Muséum National d'Histoire Naturelle (MNHN), National Institute of Water and Atmospheric Research (NIWA), National Oceanography Center, Southampton, Discovery Collections (NOCS-DC), Museum Zoologicum Bogoriense (MZB), and Korea South Pacific Ocean Research Center (KSORC). Targeted specimens that could not be directly collected for this study were acquired from museum collections and DNA extractions were attempted. Unfortunately, only a few extractions were viable; most were degraded and unusable due to their age, or exposure to formalin. An echinoid and an asteroid served as outgroup taxa, with the asteroid as the root. Echinoidea is sister to Holothuroidea forming Echinozoa, with Asteroidea part of Asterozoa, the sister group to Echinozoa (Reich et al., 2015; Telford et al., 2014). All six genes for the outgroups (Patiria miniata and Strongylocentrotus purpuratus) were downloaded from GenBank. A total of 84 terminals, both novel and published (GenBank), were used in this study (Table 1).

\subsubsection{DNA preparation and sequencing}

Tentacles or tube feet were subsampled from live animals whenever possible, placed in 95\% ethanol, and stored at $4{ }^{\circ} \mathrm{C}$. Total genomic DNA (gDNA) was extracted from subsampled tissues following the Qiagen DNeasy protocol for animal tissues. Six gene fragments were sequenced; three mitochondrial: 16S rRNA (16S, partial $671 \mathrm{bp}$ ), 12S rRNA (12S, partial 474 bp), and Cytochrome c oxidase subunit I (COI, partial $690 \mathrm{bp}$ ), and three nuclear: 18S rRNA (18S, partial 1860 bp), Histone H3 (H3, partial 335 bp), and 28S rRNA (28S, partial 995 bp). PCR reactions were performed using three different reagent mixes; either $12.5 \mu 1$ GoTaq Green Master Mix (Promega, Inc), $1.0 \mu 1$ of each primer, $1.0 \mu 1$ template DNA, and $9.5 \mu 1 \mathrm{H}_{2} 0$; or Illustra puReTaq Ready-To-Go PCR Beads (GE Healthcare, Inc), $1.0 \mu 1$ of each primer, $1.0 \mu 1$ template DNA, and $22.0 \mu 1 \mathrm{H}_{2} 0$; or $12.5 \mu 1$ REDtaq DNA Polymerase (Sigma-Aldrich, Inc), 1.0 $\mu \mathrm{l}$ of each primer, $2.0 \mu \mathrm{l}$ template DNA, and $8.5 \mu 1 \mathrm{H}_{2} 0$. Most PCR amplifications (Supplementary Material Table 1) used the following profile: 40 cycles of denaturation at $95^{\circ} \mathrm{C}$ for $30 \mathrm{~s}$, annealing at $45^{\circ} \mathrm{C}$ to $55^{\circ} \mathrm{C}$ for $40 \mathrm{~s}$, and extension at $72^{\circ} \mathrm{C}$ for $1 \mathrm{~min}$. Following PCR, the PCR product size was confirmed (via 1.5\% agarose gel electrophoresis), and the PCR product was purified ( $2.0 \mu 1$ ExoSAP-it PCR Product Clean-up with ExoSAP-it thermocycler protocol). 
The cleaned products were sequenced using cycle sequencing technology (dideoxy chain termination/cycle sequencing) on ABI 3730XL sequencers (Eurofins sequencing, www.eurofinsgenomics.com). Sequence data were edited with Geneious R6.1.6 (Kearse et al., 2012) and deposited in GenBank (Table 1).

\subsubsection{Alignment and Partitioning}

Sequences were aligned using MAFFT 7 (Katoh and Standley, 2013) with the E-INS-i strategy and each alignment was manually inspected with Geneious and Mesquite 3.10 (Maddison and Maddison, 2015). To ensure that the most robust phylogenetic inferences were made, several refinements were made on the aligned matrices. All of the rDNA alignments were first run through the Gblocks online server 0.91b (Talavera and Castresana, 2007) to remove poorly-aligned and highly-divergent areas of alignment, using the least stringent settings. Additionally, protein-coding gene alignments were analyzed with DAMBE 5.3.57 (Xia and Xie, 2001; Xia et al., 2003) to assess for substitution saturation. The Gblocks online server removed multiple positions from the original alignments $(18 \mathrm{~S}=89 \%$ retained, $12 \mathrm{~S}=80 \%, 16 \mathrm{~S}=74 \%$, $28 \mathrm{~S}=82 \%)$ and DAMBE recommended the removal of the $3^{\text {rd }}$ positions from the COI alignment. The two concatenated alignments, referred to here as 'complete' (dataset with nothing excluded) and 'reduced' (dataset excluding the positions removed by the Gblocks analyses and also excluding the COI $3^{\text {rd }}$ positions), are available in TreeBASE (www.treebase.org/). Each dataset was partitioned by both gene and codon position (for protein-coding genes: COI and H3), which resulted in nine (with COI $3^{\text {rd }}$ excluded) or ten partitions. jModelTest 2.1.4 (Darriba et al., 2012) was used to determine the best-fit models for the Bayesian inference (BI) analyses from 56 competing models, using Akaike Information Criterion (AIC) calculations. In each case the bestfit model for the BI analyses was GTR $+\mathrm{I}+\Gamma$.

\subsubsection{Phylogenetic analyses}

Maximum parsimony (MP), maximum likelihood (ML), and Bayesian inference (BI) estimators were conducted on all datasets, first on the individual gene partitions and then on the concatenated gene datasets. MP analyses were performed with PAUP* 4.0a142 (Swofford, 2002) with all characters weighted equally. Heuristic searches were conducted using random stepwise addition of the terminals (1000 replicates) with the tree bisection re-connection (TBR) 
permutation algorithm and with maximum zero-length branches collapsed. Nodal support was assessed via parsimony jackknifing (1000 replicates, 10 random additions per iteration, 37\% deletion) analyses (Farris et al., 1996). ML analyses were performed with RAxML GUI 1.5 (Silvestro and Michalak, 2012; Stamatakis, 2014) using the GTR $+\Gamma$ model of substitution as recommended by the program's author. The data was partitioned as outlined above and nonparametric bootstrapping was conducted using the same model conditions with 1000 bootstrap pseudo-replicates. BI analyses were executed using MrBayes 3.2.2 (Ronquist and Huelsenbeck, 2003). Four iterations of 50,000,000 generations were run on four chains, sampling every 1000 generations on the CIPRES Science Gateway 3.3 (Miller et al., 2010). Default priors, unlinked parameter estimates, and GTR $+\mathrm{I}+\Gamma$ for each partition were used for each iteration. Convergence and mixing of the Markov chain Monte Carlo (MCMC) runs were assessed with Tracer 1.6.0 (Rambaut et al., 2013). A majority-rule consensus tree was created from the runs, after a $10 \%$ burn-in.

Constraint analyses were conducted after the phylogenetic analyses to demonstrate statistical support for (1) the results against two existing classifications and hypotheses for Holothuroidea and (2) the ten non-monophyletic family-ranked clades recovered within Holothuroidea. The Pawson and Fell (1965) and Smirnov (2012) classifications and hypotheses were transformed into explicit trees and then used in RAxML to make constrained tree topologies (Supplementary Material Figures 1A and 1B) for the terminals used in the current study. The best ML tree topology from the reduced dataset (selected as the primary dataset, see results below) was compared to the best constrained ML trees (i.e., the best Pawson and Fell constraint tree and the best Smirnov constraint tree) from the same dataset with the approximately unbiased (AU) test (Shimodaira, 2002) in PAUP* 4.0a142 (Swofford, 2002). The best ML tree and best ML-constrained trees were then imported into PAUP*, and the AU $p$ values were recovered with the RELL method with 100,000 bootstrap replicates (Kishino et al., 1990). Constraint analyses were also performed on ten family-ranked taxa that were recovered as non-monophyletic (Synaptidae, Laetmogonidae, Synallactidae, Caudinidae, Molpadiidae, Stichopodidae, Cucumariidae, Phyllophoridae, Sclerodactylidae, and Psolidae). These were performed separately with each family constrained as a clade (Supplementary Material Figure 1 $\mathrm{C}-\mathrm{L}$ ) and the constrained tree topologies generated in RAxML with the same parameters as 
outlined previously. These constrained family trees were then compared to the best ML tree topology from the reduced dataset using the AU test as explained above.

\subsubsection{Divergence dating}

Divergence dating of the holothuroid lineages was conducted on the reduced dataset. Eleutherozoa, Echinozoa, and a series of holothuroid nodes (recovered by the current phylogenetic analyses) were constrained as clades and assigned minimum- or stem-age estimates. Age constraints were then applied to generate two datasets: a three-estimate dataset, referred to here as "3-age" (Table 2, A-C), which represented well established echinoderm dates, and a six-estimate dataset, referred to here as "6-age" (Table 2, A-F), which incorporated three lesser-known holothuroid fossil dates as well as the "3-age" dates. Initially, only one dataset was generated (6-age) using the lesser-known fossil dates, however, this led to rate discrepancies in the output trees, and analyses using well-known calibration points from outside Holothuroidea (3-age) were later performed. The BEAST v2.3.3 package (Bouckaert et al., 2014) was used to assess holothuroid divergence times using a relaxed molecular clock method (Drummond et al., 2006) and the same data partitions and conditions from the above BI analyses. BEAUti from the BEAST2 package was used to create '.xml' files with the following parameters: uncorrelated log-normal model of rate change, GTR + I $+\Gamma$ model of substitution (partitioned), Yule model of divergences, and either three (3-age) or six (6-age) fixed divergence dates (Table 2) (normal distribution) based on fossil evidence (see below). BEAST2 executed the .xml files using a random starting tree with 50 million generations for 10 separate MCMC analyses. Results were assessed for stationarity, convergence, and effective sample size with Tracer 1.6.0. The trees for the 10 runs (95\% burnin each) were combined with Log Combiner (Beast package), and then Tree Annotator (BEAST2 package) was used to generate maximum-clade credibility majority rule consensus trees with mean ages for unconstrained nodes.

Table 2 summarizes the dates for the constrained nodes used in the divergence dating analyses. Constrained ages followed a lognormal distribution around a median age and the 95\% distribution of each age is indicated.

The earliest echinoderms are reported from the Early Cambrian (Tereneuvian, 530 Ma) (Smith, 2005; Sumrall and Wray, 2007; Zamora et al., 2013). The first were likely bilateral forms, as represented by the middle Cambrian Ctenoimbricata (Zamora et al., 2012), which gave 
rise to asymmetrical cinctans and solutes. Radial symmetry ensued after the evolution of the water vascular system, with triradial helicoplacoids and later by pentaradial helicocystoids (Zamora and Rahman, 2014). Crinoids appeared soon after this rapid burst of morphological diversification, between the "Middle" Cambrian (513-524 Ma) and the Early Ordovician (Tremadocian, 479-488 Ma) (Guensburg and Sprinkle, 2001; Paul and Smith, 1984). The first eleutherozoans in the record were asterozoan-like (e.g., Maydena and Eriaster) and appeared in the Tremadocian (Jell, 2014) and Floian (both Lower Ordovician, 485 to 477 and $~ 470 \mathrm{Ma}$ respectively) (Blake and Guensburg, 2005; Lefebvre et al., 2013). Hence, 481 Ma was used with a lognormal distribution (480-488 Ma) for the crown Eleutherozoa, constrained node A, in the 3age and 6-age analyses (Table 2, A).

The earliest Holothuroidea is dated to the Middle Ordovician P. polonicus conodont zone (Darriwilian, 464 Ma, Reich, 2001; Reich, 2010a) and the earliest Echinoidea is dated to the slightly younger P. serra conodont zone (Reich in Lefebvre et al., 2013; 462 Ma, Pisera, 1994). From this, a median age of $464 \mathrm{Ma}$ with a lognormal distribution (463-465 Ma) was used for the crown Echinozoa, constrained node B (Table 2, B). The extinct "snake box"-like ophiocistioids were not considered during the dating of the Echinozoa node, since the Ordovician record for the extinct Ophiocistioidea is currently under debate (i.e., Volchovia spp. from the Dapingian and Darriwilian strata) (Reich in Lefebvre et al., 2013; Reich, 2010b; Reich and Haude, 2004; Reich and Kutscher, 2014). The date of origin for the crown group Holothuroidea, constrained node C, remains somewhat uncertain due to the group's depauperate fossil record. In the current work, the crown group Holothuroidea is identified by the presence of a calcareous ring (multiple calcareous pieces circularly arranged and connected with tentacles) and the stem-group Holothuroidea (e.g., Palaeocucumaria), in contrast, is delimited by the lack of a distinct calcareous ring, the presence of 40-50 lobate-like arranged tentacles (or "mouth tube feet"), and a single external madreporic plate (Smith and Reich, 2013). Consequently, the oldest reported crown group holothuroid fossils to date are apodan calcareous ring elements reported from early Silurian strata (Llandovery, 435 Ma Reich, 2015), thus, $435 \mathrm{Ma}$ was used as the median age (431-449 Ma) for crown Holothuroidea, constrained at node C (Table 2, C).

The oldest potential elasipodan calcareous ring elements ('Pannychiidae'), date to the late Silurian (Ludfordian, 425 to 423 Ma Reich, 2015), however, the oldest distinctly elasipodan wheel ossicles are known from younger Middle Devonian strata (late Givetian, 387 to $382 \mathrm{Ma}$ ) 
(described as myriotrochid in Boczarowski, 2001), thus, 387 Ma was used as the minimum age with a lognormal distribution (384-394 Ma) for the stem Elasipodida, constrained at node D (Table 2, D). The earliest articulated calcareous rings for Holothuriidae, constrained at node E, date only to early Middle Triassic (late Anisian, 247 to 242 Ma, Reich, 2004; Smith et al., 2013), as do the earliest holothuriid buttons (Calclamnella regularis; Stefanov, 1970). Fragmentary table ossicles that may have belonged to Holothuriidae are known from the early Late Permian (earliest Wuchiapingian, $\sim 259$ to $254 \mathrm{Ma}$ ); however, the placement of Holothuriidae with Mesothuriidae in our current analyses suggests that these table ossicles could have been from a stem group. Therefore, $246 \mathrm{Ma}$ was used as a minimum age with a lognormal distribution (244-257 Ma) for the stem Holothuriidae group (Table 2, E). The oldest Caudinidae + Molpadiidae, constrained at node F, are described from the early Late Permian (Wuchiapingian, 259 to 254 Ma Mostler and Rahimi-Yazd, 1976); however, these isolated body wall ossicles were probably of stem members. Body wall ossicles are also reported from the early Middle Triassic (Anisian, 247 to 242 Ma Speckmann, 1968), yet the earliest known undisputable Caudinidae + Molpadiidae calcareous ring material is dated to the Lower Jurassic (Sinemurian, 199 to 190 Ma, Gilliland, 1992). Since even extant Caudinidae and Molpadiidae body ossicles (ranging from "table" to "anchor" in shape, Östergren, 1897) can sometimes be confused with those from other distant families, the undisputable calcareous ring age date, 198 Ma, was used with a lognormal distribution (196-201 Ma) for stem Caudinidae + Molpadiidae group (Table 2, F).

\subsubsection{Morphological transformations}

Four holothuroid attributes were scored for mapping transformations on our phylogenetic results. These were: 1 . Respiratory trees; 2. Skeletal elements in general; 3. "Table" ossicles; 4. Tentacle shape (Supplementary Material Table 2). Four other attributes were analyzed and can be found in the Supplementary Material Table 2: depth, habitat preference, calcareous ring (CR) posterior projections, and CR foramina. The characters were scored either as binary (respiratory trees and table ossicles) or multistate (skeletal elements and tentacle shape). Voucher specimens were directly analyzed and scored for each character (Supplementary Material Table 2) if possible. Otherwise, published accounts and personal observations (listed as footnotes in the 
scoring matrices; Supplementary Material Table 2 Nexus file) were relied upon. In a few cases, characters were scored for terminals based on information for closely related taxa.

\section{Characters}

1. Respiratory trees: $0=$ absent; $1=$ present. Respiratory trees are specialized intestinal diverticula that serve as internal gas exchange organs. They lie bilaterally within the coelomic cavity and consist of ramified tubes. Presence or absence of respiratory trees has served as the basis for dividing holothuroids into major clades since Jaeger (1833). Respiratory trees can increase oxygen uptake by $60 \%$ in some species (Brown, 1979) and are sometimes used in anal suspension feeding (Jaeckle and Strathmann, 2013).

2. Skeletal elements (ossicles): $0=$ absent from body wall; $1=$ present as separated elements within the body wall; 2 = present as imbricating plates forming an outer test of varied rigidity. Ossicles are commonly found dispersed in the body walls of most holothuroids. A few holothuroids lack ossicles in their body walls, while a few others have enlarged ossicles, usually plates, that are arranged in an imbricating, or overlapping fashion all over their bodies. Holothuroids with such a robust skeleton are often said to have a "test," a condition that was deemed plesiomorphic by Pawson and Fell (1967). Terminals were only scored absent if body wall ossicles are not known in any developmental stages (some holothuroids lose their ossicles with age [Pawson, 1977]).

3. "Table" ossicles: $0=$ absent; 1 = present. "Table" ossicles may be homologous across holothuroids, albeit their variability makes defining them and assessing their distribution somewhat challenging. In general tables have a flattened disk from which a spire, comprised of one to four columns, arises orthogonal to the disk. Tables are arranged as an outer monolayer in the body wall, with the disks lying in the plane of the body wall, and the spires, often with bristled apices (crowns), projecting outward to the surface of the body wall. Here table ossicles are defined as ossicles with this shape and position. A few specialized ossicles, such as dendrochirotid "cup" ossicles and four or three armed crosses with perforated ends, are generally considered to be derived from tables (O'Loughlin et al., 2011; O’Loughlin et al., 2015; Smirnov, 2012) and were so scored.

4. Tentacle Shape: $0=$ absent (outgroups); 1 = peltato-digitate (as defined by Clark, 1908); $2=$ pinnate; 3 = digitiform; 4 = digitate $(2-4$ digits $) ; 5=$ peltate; $6=$ dendritic. Peltatodigitate tentacles have three to nine pairs of digits, no central digit (Clark, 1908) and 
digits are typically arranged in a semicircle, giving the tentacle a "palm" shape. Pinnate tentacles have a single terminal digit and paired digits that span much of the tentacle length. Digitiform tentacles are simple, unbranched, and finger-shaped. Digitate tentacles have one or two pairs of digits and lack a central terminal digit. Peltate, or shield-shaped, tentacles have a terminal disk that is either smooth or terminates in numerous short projections (papillated). Dendritic tentacles have an elongate stalk from which numerous side-branches extend and further ramify, decreasing in size toward the apex.

Character transformations were traced onto the reduced dataset ML tree topology (branch lengths included) using a Markov k-state one parameter (Mk1) model (Lewis, 2001) with Mesquite 3.10 (Maddison and Maddison, 2015).

\subsection{Results}

Sequences were obtained for $85 \%$ of the genes targeted across the 84 taxa used. Four to six genes were sequenced from all terminals, except for Echinocucumis hispida, Parastichopus tremulus, and Cucumaria miniata (three missing genes), and Myriotrochus antarcticus (five missing genes). The maximum likelihood (ML) tree for the reduced dataset is shown in Figure 3, with corresponding ML, Bayesian inference (BI), and maximum parsimony (MP) node support values where appropriate. Results from the reduced dataset are emphasized, because of saturation and poor alignment in the complete dataset. Topologies for ML, BI, and MP analyses with both the reduced and the complete dataset are shown in Supplementary Material Figure 2, along with summary statistics (Supplementary Material Table 3). Results from all analyses of both datasets were largely congruent.

The ML result of the reduced dataset was assessed with the approximately unbiased (AU) test against the best ML trees constrained with the Pawson and Fell (1965) and Smirnov (2012) hypotheses. The reduced dataset had significantly better likelihood (lnL -52038.81928) than both the Pawson and Fell (lnL -52630.36209) the Smirnov ( $\operatorname{lnL}-52401.23704)$ constrained trees. Thus the AU test rejected both these classifications, and a new one is implemented here. The ten AU tests of the reduced dataset ML tree against ML trees where the various non-monophyletic families were constrained to be clades, generally showed the unconstrained topology to be significantly better. The reduced dataset ML tree showed significantly $(p<0.05)$ better 
likelihood (lnL -52038.81928) than Synallactidae (lnL -52446.55069), Caudinidae (lnL 52210.61349), Molpadiidae (lnL -52256.98088), Cucumariidae ( $\operatorname{lnL}$-52132.07824), Phyllophoridae (lnL -52177.12494), Sclerodactylidae (lnL - 52189.73852), and Psolidae (lnL 52119.02726) constraint trees. The reduced dataset ML tree did not have significantly better likelihood when Synaptidae, Laetmogonidae, and Stichopodidae were constrained as clades. Monophyly of extant Holothuroidea was strongly supported in all analyses (Fig. 3). Apodida sensu Pawson and Fell (1965), was always highly supported as the monophyletic sister group to all other holothuroids. Within Apodida, Myriotrochidae was also strongly supported as a clade and appeared sister to the remaining Apodida in all analyses. Notably, the branch length for Myriotrochus was at least three times greater than any other branch length within the tree (Fig. 3). It appears that the Myriotrochus sp. COI sequence was responsible for this disparity (COI and all other genes except for 18S were missing for Myriotrochus antarcticus). An additional COI sequence comparison of Myriotrochus sp. and an independently sequenced myriotrochid (Smithsonian National Museum of Natural History Invertebrate Zoology Collection, Myriotrochus ahearnae paratype) demonstrated that this long branch was not due to contamination (87\% identity, Supplementary Material Table 4). Of the other Apodida sampled, Synaptidae was paraphyletic in all analyses, though a constrained monophyletic Synaptidae was not significantly worse than the best tree (see above AU test results). The ML and BI analyses of both datasets and the MP complete dataset recovered Euapta as sister to a well-supported chiridotid + Leptosynapta clade, while the MP reduced dataset analysis recovered Leptosynapta as a sister group to a Chiridota + Euapta clade. Chiridotidae was only monophyletic in the MP analyses and even Chiridota was not recovered as a clade in several of the analyses.

Apodida was sister to a uniformly well-supported clade comprising the remaining holothuroids, here termed Actinopoda following Ludwig (1889-1892) and denoting the presence of podia (Fig. 4). Within this clade, the deep-sea taxon Elasipodida (sensu Théel, 1882), as traditionally circumscribed, was polyphyletic in all analyses (Fig. 3, purple), with Deimatidae separated from the other Elasipodida families (further results below). The remaining terminals, here referred to as Elasipodida (Laetmogonidae, Psychropotidae, Elpidiidae, and Pelagothuriidae), formed a well-supported clade that was sister to all other Actinopoda (Fig. 4, purple). Within this group, Benthogone abstrusa was always recovered as sister to the pelagothuriid Enypniastes eximia and the two Pannychia terminals consistently formed a group 
sister to all other Elasipodida, thus rendering Laetmogonidae paraphyletic (Fig. 3), though a constrained monophyletic Laetmogonidae was not significantly worse than the best tree (see AU test results). All representatives of Elpidiidae and Psychropotidae formed a well-supported clade; however, their placement within Elasipodida was poorly supported.

The sister group to Elasipodida was a consistently well-supported clade (Fig. 3), here termed Pneumonophora following Selenka (1867) and denoting the presence of respiratory trees (Fig. 4). Within Pneumonophora, a clade containing representatives from all of the currently accepted genera of Holothuriidae and Mesothuriidae was well-supported in most analyses and was sister to the remaining terminals. This clade is referred to here as Holothuriida (Fig. 4). The only major topological difference between the complete and reduced datasets regarding Holothuriida was that, in the MP complete analysis, Holothuriida formed a grade with respect to the rest of Actinopoda. This result is discounted here since all other analyses recovered Holothuriida as a clade with reasonable to high support, and since this relationship has been previously suggested based on morphology (see above). Within Holothuriida, the two mesothuriid terminals always formed a group sister to Holothuriidae. Holothuriidae appeared monophyletic in all analyses, with Holothuria hilla, H. leucospilota, and Labidodemas cf. pertinax always forming a well-supported clade of vermiform holothuriids. The placement of this vermiform clade varied across analyses; the MP analyses of the complete and reduced datasets showed a Bohadschia koellikeri + Pearsonothuria graeffei clade as sister to the vermiform-shaped group, while the ML and BI analyses of both datasets (Supplementary Material Figure 2) recovered a "bread loaf'-shaped clade of Actinopyga varians (Bohadschia koellikeri + Pearsonothuria graeffei) sister to the vermiform clade.

Holothuriida was sister to a well-supported clade of the remaining Pneumonophora, which we refer to as Neoholothuriida (Fig. 4). Neoholothuriida contained two main groups in all analyses: Dendrochirotida (sensu lato), and all remaining taxa. All representatives from Dendrochirotida and Dactylochirotida were recovered in the Dendrochirotida (sensu lato) group with high support by all analyses (Fig. 3). It is referred to here as Dendrochirotida (Fig. 4). Most of the deeper nodes within the clade, however, were poorly supported and the clade's topology varied among the analyses (Supplementary Material Figure 2), with the MP topologies differing markedly from the ML and BI analyses of each dataset. Nevertheless, in all three analyses dactylochirotid terminals (all Ypsilothuriidae) were nested within Dendrochirotida, and four 
(Psolidae, Cucumariidae, Sclerodactylidae, and Phyllophoridae) of the seven represented Dendrochirotida families were consistently non-monophyletic across analyses and datasets (Fig. 4).

The other Neoholothuriida group comprised the well-supported clades Persiculida, Molpadida and Synallactida, but was poorly supported and we choose not to name it here. The new clade Persiculida included genera formerly assigned to Synallactidae (sensu Ludwig, 1894) and Gephyrothuriidae (often placed in Molpadida [e.g., Haeckel, 1896]) (Fig. 4, orange). Synallactidae was always recovered as polyphyletic in all analyses, with some terminals in Persiculida, and others intermixed with sequence representatives from Stichopodidae (sensu Haeckel, 1896). With the exception of Gephyrothuria, Molpadida included all the other molpadidan terminals used in this study (representing Caudinidae and Molpadiidae), but neither family was recovered as monophyletic in any of the analyses (Fig. 4, red). Synallactida included members from Synallactidae and Stichopodidae (sensu Haeckel, 1896) and, intriguingly, Deimatidae (sensu Théel, 1882) (Fig. 4, green), a result that was recovered in all analyses of each dataset. Within Deimatidae, Deima validum was always recovered as sister to Oneirophanta setigera + Orphnurgus glaber with high support. The Synallactidae terminals (except those that grouped with Gephyrothuria as Persiculida) along with all the Stichopodidae terminals formed a well-supported sister group to Deimatidae. Most stichopodids formed a clade in almost all analyses, except for Apostichopus, which nested among the paraphyletic grade of synallactids. The MP analyses for the complete dataset recovered a similar topology, except that Stichopodidae did form a clade (Supplementary Material Figure 2C).

\subsubsection{Molecular clock analyses}

The 3-age (Fig. 5) and 6-age (Fig. 6) Beast v2.3.3 analyses closely resembled the tree topology recovered from the ML and BI analyses (Fig. 3), apart from minor differences within Apodida, Synallactida, and Dendrochirotida on some poorly-supported branches. Substitution rates and divergence times for some key nodes, however, were markedly different between the 3age and 6-age analyses. In general, recovered substitution rates were slower in deeper branches and faster in terminal branches in the 3-age analysis. An exception to this trend was between constrained nodes $\mathrm{B}$ and $\mathrm{C}$, which showed more than twice the substitution rate of anywhere else on the tree in the 3-age analysis (Fig. 5). The 6-age analysis also showed an extremely high 
substitution rate between constrained nodes $\mathrm{B}$ and $\mathrm{C}$ and between $\mathrm{C}$ and D (Fig 6). Overall this resulted in some marked differences in age estimates at these nodes that were constrained in the 6-age analyses and left free to vary in the 3-age analyses. The elasipodid stem age, used at Node D for Actinopoda, was constrained at $\sim 387$ Ma in the 6-age analysis (Fig. 6) and was recovered with a much younger age of $281 \mathrm{Ma}$ in the 3-age analysis (Fig. 5). Stem Holothuriida (Node E) was constrained at $\sim 246 \mathrm{Ma}$ in the 6-age analysis (Fig. 6), however, it was recovered as $\sim 203 \mathrm{Ma}$ in the 3-age analysis (Fig. 5). Finally, Node F (stem Molpadida) was constrained at 198 Ma in the 6-age analysis (Fig. 6), but was recovered as $\sim 158 \mathrm{Ma}$ in the 3-age analysis (Fig. 5). Age discrepancies were also notable between the analyses for nodes that were free to vary. For instance, the most recent common ancestor (MRCA) for Apodida was $282 \mathrm{Ma}$ in the 6-age analysis (Fig. 6) but was $\sim 259$ Ma in the 3-age analysis (Fig. 5). Also, the age for the MRCA of Pneumonophora was $\sim 309 \mathrm{Ma}$ in the 6-age analysis (Fig. 6), while the 3-age analysis recovered the node at $\sim 243 \mathrm{Ma}$ (Fig. 5). The MRCA of Dendrochirotida was left free to vary in both sets of analyses, but was recovered at $\sim 182 \mathrm{Ma}$ in the 6-age analysis (Fig. 6) and $\sim 151 \mathrm{Ma}$ in the 3-age analysis (Fig. 5). In summary, constraining several nodes in Holothuroidea (Nodes D-F) in the 6age analysis led to markedly higher variation in substitution rates and older ages for unconstrained nodes relative to the 3-age analysis (Figs. 6 and 5).

\subsubsection{Transformation analyses}

The ML transformation on the ML tree topology for the reduced dataset showed that respiratory trees evolved once in the branch leading to Pneumonophora (proportional likelihood $>0.95$ ), and were afterwards lost once in Deimatidae (Fig. 7A). Transformation analyses further suggested that free body wall ossicles are plesiomorphic, while a "test" arose several times within Dendrochirotida, and that body wall ossicles were probably lost twice, at the origins of Persiculida (proportional likelihood $>0.95$ ) and Pelagothuriidae (represented here by Enypniastes eximia) (Fig. 7B).

The evolutionary history of table ossicles appears less clear. It is possible that table ossicles arose once at the origin of Pneumonophora (proportional likelihood $\sim 0.5$ ) and underwent multiple independent losses and modifications (Fig. 7C). When the transformation was assessed using a parsimony criterion there were four most parsimonious reconstructions (MPR) of 12 steps. The MPR that maximized the homology of table ossicles showed three 
origins (including one below the node for Pneumonophora) and nine losses, while the other MPRs showed up to eight origins and fewer losses.

Tentacle shape is a longstanding diagnostic character in holothuroid taxonomy. The plesiomorphic condition for Holothuroidea was ambiguous (Fig 7D). Peltate tentacles at the base of Actinopoda and peltato-digitate tentacles at the base of Apodida had high proportional likelihood support. Dendritic tentacles were strongly supported at the base of Dendrochirotida (proportional likelihood $>0.95$ ), as were two independent origins of digitate tentacles (with two to four digits) in Molpadida and in Gephyrothuria alcocki.

\subsection{Discussion}

This is the first broad-scale molecular phylogenetic analysis of Holothuroidea allowing for a reassessment of the relationships of these highly derived echinoderms. The approximately $4.3 \mathrm{~kb}$ of sequence data obtained from mitochondrial (COI, 16S, 12S) and nuclear (H3, 18S, $28 \mathrm{~S}$ ) sources, was analyzed under a variety of methods which consistently recovered a series of well-supported nodes. This allows for the broad-scale taxonomy of Holothuroidea to be revised with some confidence. Apodida is a well-established taxon that was recovered as a clade with a high level of support and little revision is required. Elasipodida, Dendrochirotida and Molpadida are three other traditionally used names that are reformulated here to accommodate three wellsupported clades recovered in the current study. Old names that have long been disregarded, namely Actinopoda and Pneumonophora, are reintroduced, as well as several new major taxa: Holothuriida, Neoholothuriida, Persiculida and Synallactida. Linnaean ranks are not applied to these more inclusive taxon names as there are not enough ranks to sufficiently reflect even the broad-scale topology of the tree (see Pleijel and Rouse, 2003). The reader is referred to Figure 4 and to the indented naming system below that reflects the hierarchy of names used here (not including family or genus-ranked taxa; see Figure 3).

\subsubsection{Holothuroidea}

Apodida

Actinopoda

Elasipodida

Pneumonophora 


\section{Holothuriida \\ Neoholothuriida \\ Dendrochirotida \\ Persiculida \\ Molpadida \\ Synallactida}

\subsubsection{Apodida}

The Apodida terminals formed a well-supported clade in all analyses (Fig. 3, yellow), and, as proposed by numerous authors (Becher, 1909; Cuénot, 1948; Haude, 1992; Kerr, 2001; Lacey et al., 2005; Littlewood et al., 1997; MacBride, 1906; Reich, 2010a; Semper, 1867-8; Smirnov, 2012), was recovered as sister to all other holothuroids. Although Smirnov (2012) named this clade Synaptida (Cuénot, 1891), we use the older (derived from Brandt, 1835) and widely-accepted (Paulay and Hansson, 2013) name, Apodida, here. Within Apodida, Myriotrochidae was sister to the remaining Apodida taxa as long recognized (Kerr, 2001; Östergren, 1907; Smirnov, 1998; Smirnov, 2012). The long branch leading to Myriotrochidae (Fig. 3) was caused by the highly divergent Myriotrochus sp. COI sequence, as none of the other four gene sequences $(18 \mathrm{~S}, 28 \mathrm{~S}, 16 \mathrm{~S}$, or $\mathrm{H} 3)$ demonstrated major branch length differences relative to the other holothuroid taxa. The Myriotrochus sp. COI sequence was validated in comparison with a COI sequence from Myriotrochus ahearnae, which also showed high divergence from other Holothuroidea but close similarity to Myriotrochus sp. (Supplementary Material Table 4). Further investigation is warranted as to why these myriotrochid COI sequences, which also result in markedly different amino acid sequences, show such differences from the rest of Holothuroidea. Lastly, the paraphyletic relationship of synaptids relative to chiridotids is surprising and warrants further phylogenetic analysis.

\subsubsection{Actinopoda}

The presence or absence of podia (pedicels and papillae) has long been recognized as a key character for Holothuroidea (e.g., Brandt, 1835; Jaeger, 1833; Ludwig, 1889-1892). Few authors have applied a name for the holothuroid clade that is sister to Apodida, a group that was consistently recovered with high support by all analyses in the current study (Fig. 3). Potential 
apomorphies include peltate tentacles, radial ambulacral canals, and podia. However, peltate tentacles appear to have undergone subsequent reversals in parts of the clade (e.g., Dendrochirotida and Molpadida) (see below Character Transformations 1.4.3). Brandt (1835) named a group Pedatae for those holothuroids with tube feet, as opposed to his Apodes for those without tube-feet, but the name Pedatae, or Pedata, has rarely been used. Ludwig (1891) also divided Holothuroidea into two major groups Actinopoda and Paractinopoda, which he based on the morphology of the ambulacral system. His Actinopoda included representatives from Aspidochirotida, Elasipodida, Dendrochirotida and Molpadida, thus corresponding to the clade here recognized, unlike the more fluid concept of Brandt (1835). Actinopoda, erected by Calkins (1909), is a name that has been applied at various taxonomic levels for protists including Radiolaria and Heliozoa. These taxa, however, are now considered a polyphyletic assemblage and the name is no longer in common use (Adl et al., 2012; Ishitani et al., 2011). Therefore, the name Actinopoda is here resurrected for the holothuroid sister group to Apodida (Fig. 4).

\subsubsection{Elasipodida}

The traditionally formulated Elasipodida was recovered as polyphyletic in all analyses (Fig. 3), with Deimatidae consistently recovered within Synallactida (Fig. 4), while the remaining Elasipodida terminals formed a well-supported clade. The name Elasipodida is here applied to this latter clade (Fig. 4, purple). Taxonomic relationships among Elasipodida families have varied over the years (see Becher, 1909; Cuénot, 1948; Haeckel, 1896; Ludwig, 1891; MacBride, 1906; Östergren, 1907; Perrier, 1902; Théel, 1882), and a few authors have called attention to the poor fit of deimatids. For instance, Perrier (1902) and Becher (1909) hypothesized Deimatidae as a group within Aspidochirotida, while Ekman (1925) and Hansen (1975) noted differences (e.g., gonad structure) between Deimatidae and the rest of Elasipodida. Recently, Smirnov $(2012,2016)$ removed Deimatidae from Elasipodida and placed it in Aspidochirotida on the basis of calcareous ring shape, ossicle morphology, and an unpublished molecular phylogenetic analysis (Solís-Marín, 2003).

Within Elasipodida, members of four family-ranked taxa were represented: Elpidiidae, Laetmogonidae, Pelagothuriidae, and Psychropotidae. Elpidiidae and Psychropotidae were always recovered with strong support, but their positions within Elasipodida were poorly resolved. Laetmogonidae, although not statistically non-monophyletic (AU tests), was always 
recovered as paraphyletic; Pannychia was always sister to the other Elasipodida, and Benthogone abstrusa was always sister to the pelagothuriid Enypniastes eximia, though with poor support. Consequently, the main morphological characters that currently diagnose Laetmogonidae, namely the absence of lateral papillae and presence of wheel ossicles (Smirnov, 2012), are possibly plesiomorphies and may need reassessment. The systematic position of Pelagothuriidae has long been debated (Cuénot, 1948; Haeckel, 1896; Hansen, 1975; Kerr and Kim, 2001; Östergren, 1907; Perrier, 1902). Our study does not support a relationship between Pelagothuriidae and Psychropotidae (Gebruk, 1990), or that Pelagothuriidae should be removed from Elasipodida (Heding, 1950). It will be interesting to see where the other known pelagothuriid, Pelagothuria natatrix (Fig. 1A), the only wholly pelagic echinoderm, falls in future phylogenetic analyses.

\subsubsection{Pneumonophora}

Although respiratory trees have been considered an important character in holothuroid classification since Jaeger (1833), there have been few names applied to the large well-supported respiratory tree-possessing clade that our study recovered as sister to Elasipodida. Early workers divided Holothuroidea into clades with and without respiratory trees, which correspond to Apodida and Pneumonophora here, as Elasipodida was then unknown (e.g., Müller, 1850; Selenka, 1867; Semper, 1867-8). The discovery of Elasipodida by Théel (1879) introduced a group without respiratory trees but with podia, and the relationships of Apodida, Elasipodida, and other clades have been diversely interpreted since. The topology supported here, where Elasipodida is sister to Pneumonophora, was first proposed by Cuénot (1891) and has been supported recently by the phylogenetic analyses of Kerr \& Kim (2001) and Lacey et al. (2005). Smirnov (2012) called this clade Holothuriacea in his review; however, the name Pneumonophora is preferred here since respiratory trees are a clear synapomorphy for the group and it is an older name. Two major clades were recovered within Pneumonophora: Holothuriida and Neoholothuriida.

\subsubsection{Holothuriida}

The present study consistently recovered Holothuriidae + Mesothuriidae as a wellsupported sister group to all other Pneumonophora (Fig. 4, light blue), thereby warranting the 
new name, Holothuriida. The distinctiveness of mesothuriids and their potential relationship to holothuriids has a long history (Becher, 1909; Sluiter, 1901a), but this has not been recognized recently and they have lately been placed in Synallactidae. Solís-Marín's (2003) unpublished molecular study showed that Synallactidae was divided into 'Mesothuriidae,' a clade with gonads in a single tuft, and a clade of all other synallactids possessing paired gonads. Smirnov (2012) formally erected Mesothuriidae, which he placed in his order Aspidochirotida (Fig. 2O). While Synallactidae has long been recognized (Heding, 1940; Koehler and Vaney, 1905;

Ludwig, 1894; Perrier, 1898), our results also show that the group is polyphyletic even with the removal of mesothuriids (see below section 1.4.10). The restriction of the gonad to one side of the dorsal mesentery is a synapomorphy of Holothuriida.

\subsubsection{Neoholothuriida}

The morphologically-heterogeneous Neoholothuriida, a new taxon erected here, includes members that were previously scattered across other major holothuroid taxa: Aspidochirotida, Dendrochirotida, Dactylochirotida, Molpadida, and Elasipodida. Although Neoholothuriida has only one known uniting character - known members show two gonads, one on either side of their dorsal mesentery -, four morphologically well-defined and well-supported clades (Fig. 4) can be identified within it: Dendrochirotida, Persiculida, Molpadida and Synallactida.

\subsubsection{Dendrochirotida}

The long-recognized Dendrochirotida is still strongly supported and is a morphologically well-defined clade. The group is united by the possession of an introvert: clearly separated retractor muscles are attached to the pharyngeal complex and withdraw the tentacles and anterior end of the animal into the body. Pawson and Fell (1965) distinguished their newly recognized Dactylochirotida by their simplified (sometimes digitiform) tentacles and the development of a "test," which both now appear to be derived conditions that have evolved more than once within Dendrochirotida (see below Character Transformations 1.4.3). Smirnov (2012, 2016) believed that these two characters arose multiple times within Dendrochirotida and did not recognize Dactylochirotida, which he considered polyphyletic. Although Dactylochirotida should clearly be dismissed, the relationships within Dendrochirotida are less obvious; at least four (Psolidae, Cucumariidae, Sclerodactylidae, and Phyllophoridae) of the eight represented families appear 
non-monophyletic in our analyses and remain poorly resolved (Fig. 4). Thus, the short internal branch lengths, and correspondingly poor topological support, make taxonomic revision within the clade unwise at this time. Michonneau and Paulay (2014) analyzed partial COI sequence data from several Phyllophoridae and also showed that several genera were non-monophyletic. Their results agree with the results of this study, which together suggest that the morphological characters (often only one or two) currently used to diagnose family and generic-level taxa within Dendrochirotida need reexamination and that a major taxonomic revision of Dendrochirotida is warranted. Smirnov (2012) also recently proposed a major overhaul of the family-level classification of the order, but without a supporting phylogenetic analysis. Thus, the relationships within Dendrochirotida remain unresolved and await more in depth study.

\subsubsection{Persiculida}

A new taxon, Persiculida, is erected for a well-supported clade also characterized by lack of body wall ossicles, presence of a posterior (pygal) furrow, and, potentially, characteristic secondary chemistry (Kalinin et al., 2005; Silchenko et al., 2004). This group includes three genera generally classified in Synallactidae (Aspidochirotida) and one generally classified in Gephyrothuriidae (Molpadida) (Fig. 4, orange). O'Loughlin and Ahearn (2005) identified a “pygal-furrowed” group of Synallactidae, containing Molpadiodemas and Pseudostichopus, as one lacking body wall ossicles and having a vertical posterior furrow. We consistently recovered a clade with these morphological characters that included these genera in addition to Paroriza and Gephyrothuria (formerly in Molpadida). We name the clade Persiculida (Latin persica $=$ peach,+ culus $=$ posterior $)$, as the pygal furrow resembles a 'cleft on a peach'. Gephyrothuria (Gephyrothuriidae) has been shuffled between Aspidochirotida and Molpadida since its description by Koehler and Vaney (1905) (see O'Loughlin [1998] for review). Östergren (1907), considered Gephyrothuria as sister to Synallactidae, which prompted Heding (1935) to create the monotypic order Gephyrothurioidea, which he characterized as a group that lacked caudal appendages, tentacular ampullae, and paired longitudinal muscles. Later, Heding (1940) moved Gephyrothuria back into the order Aspidochirotida when he created his family Gephyrothuriidae and its two subfamilies, Gephyrothuriinae and Benthostichopodinae. These two subfamilies included the genera Pseudostichopus, Paroriza, Molpadiodemas, Gephyrothuria, and Benthothuria, and thus, Heding's Gepyrothuriidae corresponds closely to the Persiculida 
recognized here, except for the inclusion of Benthothuria (a genus we did not sample) that remains to be phylogenetically evaluated. Recently, Smirnov (2012) recognized a separate order (Gephyrothuriida) for Gephyrothuriida (sensu stricto) (including Hadalothuria; see also O'Loughlin [1998]) based largely on Heding's (1935) characters (e.g., calcareous ring, tentacles, and tentacle ampullae morphology).

Paroriza prouhoi was always well supported as sister to Gephyrothuria alcocki, the type taxon of Gephyrothuriidae, and we here recommend that Paroriza be considered part of Gephyrothuriidae (Fig. 4, Gephyrothuriidae [2]). With Paroriza reassigned to Gephyrothuriidae, and with Synallactes (the type taxon for Synallactidae) recovered within Synallactida, the two remaining clades formerly of Synallactidae (sensu Pawson and Fell 1965) that now lie within Persiculida also warrant new names (Fig. 3, Molpadiodemas and Pseudostichopus).

We designate a new family Molpadiodemidae (Fig. 4, Molpadiodemidae) to include members of the genus Molpadiodemas, and a new family Pseudostichopodidae (Fig. 4, Pseudostichopodidae) to include members of the genus Pseudostichopus. Both of these families can be diagnosed by morphological characters recognized by O'Loughlin and Ahearn (2005) (Appendix A for the formal diagnoses).

\subsubsection{Molpadida}

Despite its uncertain position within Neoholothuriida, the results of the current study reveal Molpadida (sensu Pawson and Fell, 1965) as a non-monophyletic group (Fig. 3) and, as discussed above, suggest that Gephyrothuria (Gephyrothuriidae) be moved to Persiculida (Fig. 4). Of the three remaining currently accepted families of Molpadida (Paulay and Hansson, 2013), Molpadiidae and Caudinidae were non-monophyletic, yet always strongly recovered as a clade; Eurpyrgidae was not represented. Molpadida without Gephyrothuriidae has always formed a well-recognized grouping. In the past, some taxonomists grouped Molpadida with, or within, Apodida because members of the group lacked obvious tubefeet (Brandt, 1835; Bronn, 1860; Burmeister, 1837; Pawson and Fell, 1965; Perrier, 1902; Théel, 1886). Our analyses clearly placed Molpadida away from Apodida, as part of the well-supported Neoholothuriida. The loss of tubefeet in Molpadida may have been driven when benthic neoholothuriids with respiratory trees switched to an infaunal lifestyle (Shick, 1983), an idea that is supported by fossil evidence; the first appearance of molpadidan sea cucumbers coincides with the general trend of Mid- 
Mesozoic marine infaunalization (Kier, 1982; Kier, 1987; Stanley, 1977; Vermeij, 1977). Though clearly not closely related to Apodida, the position of Molpadida within Neoholothuriida remains uncertain. The current study places Molpadida as sister to Synallactida with poor support (Fig. 3); however, the close relationship of Molpadida to Dendrochirotida was and is the favored arrangement by other authors (Clark, 1910; Haeckel, 1896; Kerr and Kim, 2001; Ludwig, 1889-1892, 1891; MacBride, 1906; Smirnov, 2012).

\subsubsection{Synallactida}

We name the clade that forms a polytomy with Persiculida and Molpadida (see Fig. 4 polytomy) Synallactida. It is currently unclear which morphological synapomorphies support Synallactida, although most known species are epibenthic. Many Synallactida (e.g., Stichopus, Isostichopus, Synallactes, and Bathyplotes) also display a unique defense behavior - they will shed their outer body walls - when they are disturbed or attacked (see Kropp, 1982). Further research might demonstrate that this behavior is prevalent throughout the clade, excluding Deimatidae.

Within Synallactida, the three terminals of Deimatidae were always recovered as sister to a clade comprising stichopodids and synallactids. Since Synallactes (the type genus of Synallactidae) was always recovered as the sister group to a strongly-supported clade of other synallactids and stichopodids, the name Synallactidae is only applied to Synallactes in this study. This suggests that the other represented synallactid genera, Bathyplotes and Paelopatides, be moved to Stichopodidae (Fig. 4, [1]). As discussed above, we consistently recovered Synallactidae (sensu Ludwig, 1894) as polyphyletic, a result that supports Smirnov's (2012) speculation that Synallactidae needs revision. However, the current study suggests that his proposed solution of having two subfamilies, "Pseudostichopodinae" and "Synallactinae," is insufficient. An alternative solution might be to combine both the stichopodid and restricted synallactid taxa within Synallactida under Synallactidae.

\subsubsection{Time-tree analyses}

The same three nodes (Nodes A-C) were calibrated in each of the divergence time analyses (3-age and 6-age). These were relatively uncontroversial crown group dates for Eleutherozoa (Blake and Guensburg, 2005; Jell, 2014; Lefebvre et al., 2013), Echinozoa 
(Lefebvre et al., 2013; Pisera, 1994; Reich, 2001; Reich, 2010a), and Holothuroidea (Reich, 2001; Reich, 2010a). For the 3-age analyses the remaining nodes (all nodes excluding Nodes AC) were left free to vary. In contrast, for the 6-age analyses a further three additional constraints (Nodes D-F) were applied for clades within Holothuroidea (Table 2). This addition of further constrained dates within Holothuroidea yielded some marked effects, as these nodes were seen as much younger in the 3-age analyses (Figs. 5 and 6). For instance, under the 3-age analyses it appears that two to three holothuroid lineages survived the end-Permian extinction event ( 252 Ma), while the 6-age analyses showed at least five survived. All analyses revealed the rate of molecular evolution within a similar range of values across the tree, except for some internodes near the base of the tree. The dramatic increase in the molecular rate of evolution that is seen between nodes $\mathrm{B}$ and $\mathrm{C}$ in both analyses and between $\mathrm{C}$ and $\mathrm{D}$ in the 6-age analyses compared to the 3-age analyses does raise concern that the placement of holothuroid fossils as representatives of certain extant lineages (see Materials and Methods 1.2.5) may need reassessment. The most dramatic difference between the two age trees is the 100 Ma discrepancy seen when Actinopoda (all holothuroids besides Apodida) was constrained by stem date "D" ( 387 Ma) in the 6-age analyses (Fig. 6), compared to when this node was free to vary in the 3-age constraints analyses (Fig. 5) ( 281 Ma). Although several distinct actinopodid ossicles (Tribrachiodemas ordovicicus; Reich, 2010c), calcareous ring elements ("pannychiid" radial elements; Reich 2015a), and body fossils (unnamed taxon with deimatid affinities; Reich and Smith, 2011) are recorded from the Early Paleozoic, the major age discrepancy and marked molecular rate of evolution between Nodes $\mathrm{C}$ and $\mathrm{D}$ suggest that these fossils may need re-examination.

What is consistent in both of the age-constraint analyses is that Apodida and Actinopoda independently transitioned the end-Permian extinction (Figs. 5 and 6). Within Apodida, the unconstrained nodes showed similar age differences in both the 3-age and 6-age analyses, and although the distinctions between stem and crown group myriotrochid and chiridotid fossil wheel ossicles are uncertain, both of the divergence time analyses place the myriotrochid and chiridotid most recent common ancestor (MRCA) within the same approximate age (Permian). Within Actinopoda the unconstrained nodes also showed similar age differences in both the 3-age and 6age analyses. The late origin of Dendrochirotida recovered here raises questions about Jell's (2010) identification of the Silurian body fossil Porosothyone picketti as a member of Dendrochirotida and instead supports Smith and Reich (2013) who placed this taxon as sister to 
Apodida. It appears that the detailed structure of the calcareous ring of Porosothyone, a central perforation for the radial nerve and three anterior prolongations, was misinterpreted by Jell as a depression and posterior prolongations, respectively. This emphasizes the need for further fossil exploration and anatomical reviews of extant holothuroids (with emphasis on the calcareous ring).

\subsubsection{Character Transformations}

The results of this study raise interesting issues with regard to the utility of currently employed morphological features diagnosing current holothuroid taxonomy (Fig. 4).

\subsubsection{Respiratory tree}

The origin of holothuroid respiratory trees and their systematic significance has long been debated (Brandt, 1835; Jaeger, 1833; Müller, 1850; Selenka, 1867). Recent systematic, morphological, and molecular works (Kerr and Kim, 1999; Kerr and Kim, 2001; Lacey et al., 2005; Smirnov, 2012) (Fig. 2 L, M, and O), as well as the results of the current study (Fig. 7A), support one of the oldest theories (Selenka, 1867; Semper, 1867-8) that suggested that respiratory trees are derived and evolved once within Holothuroidea. The current study places this derivation as an apomorphy for Pneumonophora, with one obvious loss, occurring in Deimatidae. This loss in Deimatidae was hypothesized recently by Smirnov $(2012,2016)$ and contradicts the current widely-accepted view that Deimatidae be placed within Elasipodida (e.g., Paulay and Hansson, 2013). It is unclear why deimatids lost their respiratory trees. However, transformations of general holothuroid shape and habitat preference (Supplementary Material Table 2) suggest that oxygen availability and body wall thickness might be guiding factors. Holothuroids with respiratory trees receive approximately half of their oxygen through these structures, and the rest through diffusion across their body surface (Brown, 1979). Shick (1983) suggested that the direct uptake of oxygen by respiratory trees and a thick body wall with a reduced skeleton may have allowed holothuroids to occupy "creviculous" habitats unavailable to most testaceous echinoderms. Possibly the reverse conditions transpired in Deimatidae; their remarkably thin body walls (hydrostatic skeleton comprised of large compact plates, mentioned above), low metabolic demands (many reside in the deep sea where it is cold and oligotrophic), and their open epibenthic habits may have decreased their need for respiratory trees. 


\subsubsection{Skeletal elements}

A reduced skeleton of body wall ossicles is plesiomorphic for Holothuroidea (Fig. 7B), and it was from this state that the "absent" and "testate" forms derived independently several times. Holothuroids without ossicles in their body walls may have ossicles in their tube feet, tentacles, gonads, pygal lobes, and respiratory trees (O'Loughlin and Ahearn, 2005). According to the transformation analysis (Fig. 7B), such an "absent" skeletal type is an apomorphy for Persiculida and possibly Pelagothuriidae (the only other pelagothuriid, Pelagothuria natatrix, lacks body wall ossicles [Ludwig, 1894], but was not represented here). The lack of ossicles in some other holothuroids (e.g., Achiridota, Kolostoneura) not represented here, are likely independent and derived losses, and it is likely that more genera with the "absent" skeletal type (e.g., Hadalothuria, Benthothuria, Hansenothuria, and Meseres) may belong to Persiculida. Holothuroids without body wall ossicles are rare and understudied, thus the reasons for their lack of ossicles are poorly understood; however, it could be that these species are hindered by ossicles or that they have replaced them with alternative structures. For example, ossicles could have been lost in Pelagothuria natatrix and Enypniastes eximia - "pelagic" and "benthopelagic" (respectively) species which spend a majority of their time in the water column (Miller and Pawson, 1990) - because they added weight and were disadvantageous. Enypniastes eximia also has bioluminescent granular bodies in their body walls that they can "slough off" when they are physically disturbed (Robison, 1992); it is possible that ossicles might have interfered with this defensive technique. Some Pseudostichopus (Persiculida) species cover themselves with sponge spicules, foraminifera, or other hard debris (O'Loughlin and Ahearn, 2005) that may act as alternatives to ossicles. Interestingly, Heding (1935) also mentions a "conspicuous thick layer of cartilaginous-like tissue between the cutis and the transverse-muscles" of Molpadiodemas acaudum (= M. atlanticus), which may stiffen the body wall in the same manner as ossicles. Although they do not lack body wall ossicles entirely, many members of Molpadida will transform their ossicles into phosphatic deposits as they age (Pawson, 1977; Pawson et al., 2001). It has been speculated that such an alternative phosphatic skeleton may be more suitable in the low-oxygen environments where many of these species reside (Rhoads and Morse, 1971). More research is needed to test these theories. 
Holothuroids with a "testate" skeleton tend to have large imbricating plate ossicles in their body walls. Pawson and Fell (1965) and Haude (1992; 1995) suggested that extant holothuroids with isolated ossicles arose from heavily-plated or testaceous holothuroids, while both Kerr and Kim (1999) and Smirnov (2015) suggested that the "test" represents a later innovation. Our results support the latter hypothesis and clearly indicate that the "test" skeletal type arose once or several times (e.g., Haude, 2002) within Dendrochirotida (Fig. 7B).

\subsubsection{Table ossicles}

Much has been written about relationships among diverse ossicle types in sea cucumbers, but homologies and evolution of ossicle types remains poorly constrained. Tables are one of the more widespread and recognizable ossicles, and are considered an important diagnostic character for many holothuroid groups (Smirnov, 2012). Gilliland (1993) and Smirnov (2012) postulated that various types of table ossicles appeared and developed independently across Holothuroidea, with Smirnov further believing that "lung holothurians" (Smirnov's subclass Holothuriacea $=$ our clade Pneumonophora Fig. 4) had the "ability to develop a spire from several closely spaced 2-4 pillars." In contrast, Kerr and Kim (2001) suggested that a clade of holothuroids with table ossicles diverged from elasipodan-like ancestors by the Middle Devonian. The table ossicle transformation in the current study (Fig. 7C) was ambiguous and does not resolve this controversy. Table ossicles were found to either be an apomorphy for Pneumonophora with subsequent losses, or to have evolved multiple times within derived Holothuroidea (Fig. 7C).

\subsubsection{Tentacle shape}

Tentacles are an apomorphy for Holothuroidea; however, the plesiomorphic tentacle form remains unclear. Most tentacle types, such as digitiform, digitate, and dendritic, appear to have evolved from a general peltate tentacle form (Fig. 7D), and certain tentacle morphologies appear as apomorphies for certain clades (e.g., Dendrochirotida). Although few studies have investigated the functionality of holothuroid tentacles (e.g., Roberts and Bryce, 1982; Sun et al., 2015), it is thought that tentacle shape corresponds with food type (Smirnov, 2016) and habitat preference, and that this "resource partitioning" might help avoid competition for food (Roberts and Moore, 1997). For example, Roberts and Moore (1997) suggested that the peltate and digitate tentacles of some deep-sea deposit-feeding holothuroids (e.g., Oneirophanta mutabilis, 
Psychropotes longicauda, and Paroriza pallens) may be adaptations to the specific sediments on which they feed, and that their selected diets may limit their competition for food in occasionally oligotrophic environments.

\subsubsection{Other morphological characters}

Although we did not perform transformation analyses for them, one traditional and two novel characters appear as clear apomorphies for clades recovered by the current study. Many classical holothuroid systematists gave precedence to the presence or absence of tubefeet above all other recognized characters (e.g., Brandt, 1835; Burmeister, 1837; Lampert, 1885). Brandt (1835) made the first holothuroid system using this character; however, Ludwig's (1889-1892) system fits closest to the tree topologies recovered here. Given their presence in Echinoidea and other echinoderms, tubefeet are plesiomorphic for Holothuroidea and their absence in Apodida and their reductions (mid-body tube feet) in Molpadida are likely apomorphic conditions.

In addition to the traditionally used characters discussed above, the current phylogeny suggests two novel morphological apomorphies for two main holothuroid clades. The first is the presence of gonads on one side of the dorsal mesentery, which supports Holothuriida, and the second is the presence of a posterior vertical furrow, which supports Persiculida. More research is needed to assess the evolution of these features, as well as clarify which morphological apomorphies may characterize some of the large clades identified here (e.g., Neoholothuriida and Synallactida). With the well-supported holothuroid higher-level phylogeny presented here, transformation analyses of other morphological features may prove rewarding. For example, some have proposed that the morphology of the calcareous ring may have high systematic value (Pawson and Fell, 1965; Reich, 2015; Reich and O'Loughlin, 2010; Smirnov, 2012).

\subsection{Conclusion}

This is the first phylogenetic study to assess the higher-level relationships of Holothuroidea using a multi-gene approach, including molecular data from multiple difficult-toaccess (deep-sea and polar) taxa. The results of the current study complement and extend those of recent molecular (Lacey et al., 2005) and morphological (Kerr and Kim, 2001) phylogenetic analyses, as well as taxonomic works incorporating these findings (Smirnov, 2012). However, systematic revisions for a series of well-supported clades are also introduced in this study 
because it was revealed that a large-scale revision of Holothuroidea was necessary. Extant holothuroids fall into two main clades: Apodida and Actinopoda. Within the latter taxon, Pneumonophora and Elasipodida are recognized, as well as a series of smaller clades within Pneumonophora: Holothuriida and Neoholothuriida (containing Molpadida, Persiculida, Synallactida, and Dendrochirotida). Although there is strong support for most of the clades across all analyses, low support for a few (e.g., Molpadida + Synallactida + Persiculida) makes it clear that more data are necessary. Fortunately, advances in next-generation sequencing methods allow for the fast and relatively easy processing of much more data than presented here (e.g., Liang et al., 2013; O'Hara et al., 2014; Ozsolak and Milos, 2010). Holothuroids have a series of traits that are homoplastic, such as ossicles, tentacles, and tubefeet and the current study demonstrates the limited utility of some of these in systematics. Time-tree analyses also suggest that assignment of several holothuroid fossils may need reassessment.

\subsection{Acknowledgements}

We thank David and Doris Pawson for their valuable insight and for kindly inviting AKM to the Smithsonian National Museum of Natural History to identify specimens with them. Niki Davey (NIWA) kindly provided rare tissue samples and specimens, Mark O’Loughlin provided tissue samples, and Phil Zerofski (SIO) collected California specimens. Sun Kim is thanked for inviting AKM on the field expedition to Chuuk where multiple specimens were obtained. The Korea South Pacific Ocean Research Center (KSORC) and Korean Ocean Research and Development Institute (KORDI) are thanked for lodging and supporting the echinoderm collection team in Chuuk. We are grateful to the crew of the R/V IB Nathaniel B. Palmer and science participants during the cruises NBP-11-05 and NBP-13-03; the Guam Marine Lab staff and students for their boat support and assistance; National Oceanographic and Atmospheric Administration, the Oscar Elton Sette crew, and principal investigators (Joseph O’Malley and Donald Kobayashi) for inviting AKM on cruises around the Marianas Islands where multiple specimens were obtained. We thank Maria Celia (Machel) Malay and Daniel Lindstrom who reviewed earlier drafts and discussions with Mark O'Loughlin and Ahmed Thandar. AKM would like to especially thank JCC and MM for their endless support.

Funding: This work was supported by the U.S. National Science Foundation Assembling the Echinoderm Tree of Life project [grant numbers DEB 1036219, 1036368], the National Science 
Foundation Office of Polar Programs [OPP 1043749] and the Western Pacific Coral Reef Institute (National Centers for Coastal Ocean Science).

\subsection{References}

Adl, S.M., Simpson, A.G.B., Lane, C.E., Lukeš, J., Bass, D., Bowser, S.S., Brown, M.W., Burki, F., Dunthorn, M., Hampl, V., Heiss, A., Hoppenrath, M., Lara, E., le Gall, L., Lynn, D.H., McManus, H., Mitchell, E.A.D., Mozley-Stanridge, S.E., Parfrey, L.W., Pawlowski, J., Rueckert, S., Shadwick, L., Schoch, C.L., Smirnov, A., Spiegel, F.W., 2012. The revised classification of eukaryotes. J. Eukaryot. Microbiol. 59, 429-514.

Arndt, A., Marquez, C., Lambert, P., Smith, M., 1996. Molecular phylogeny of eastern Pacific sea cucumbers (Echinodermata: Holothuroidea) cased on mitochondrial DNA sequence. Mol. Phylogenet. Evol. 6, 425-437.

Becher, S., 1909. Die Stammesgeschichte der Seewalzen. Ergeb. Fortschr. Zool. 1, 403-490.

Blake, D.B., Guensburg, T.E., 2005. Implications of a new early Ordovician asteroid (Echinodermata) for the phylogeny of asterozoans. J. Paleontol. 79, 395-399.

Boczarowski, A., 1997. Mistaken identity of wheel-shaped sclerites of Ophiocistioidea and Holothuroidea. Slovak. Geol. Mag. 3, 331-340.

Boczarowski, A., 2001. Isolated sclerites of Devonian non-pelmatozoan echinoderms. Palaeontol. Pol. 59, 3-220.

Bouckaert, R., Heled, J., Kuehnert, D., Vaughan, T., Wu, C.-H., Xie, D., Suchard, M., Rambaut, A., Drummond, A., 2014. BEAST 2: A software platform for Bayesian evolutionary analysis. PLoS Comput. Biol. 10, e1003537.

Brandt, J.F., 1835. Prodromus descriptionis animalium ab H. Mertensio in orbis terrarum circumnavigatione observatorum. Fascic. I., Polypos, Acalephas Discophoras et Siphonophoras, nec non Echinodermata continens. Recueil Actes des séances publiques de l'Acadadémie impériale des Science de St. Pétersbourg 1834, 201-275.

Bronn, H.G., 1860. Klassen und Ordnungen der Strahlenthiere (Actinozoa), wissenschaftlich dargestellt in Wort und Bild. C.F. Winter'sche Verlagshandlung, Leipzig.

Brown, W.I.a.S., J. M., 1979. Bimodal gas exchange and the regulation of oxygen uptake in holothurians. Biol. Bull. 156, 272-288.

Burmeister, H., 1837. Handbuch der Naturgeschichte: Zum Gebrauch bei Vorlesungen. Zweite Abtheilung. Zoologie. Theod. Chr. Friedr. Enslin, Berlin.

Calkins, G.N., 1909. Protozoölogy. Lea and Febiger, New York.

Clark, H.L., 1908. The apodous holothurians. A monograph of the Synaptidae and Molpadiidae. Smithsonian Contributions to Knowledge 35, 1-231.

Clark, H.L., 1910. The development of an apodous holothurian (Chiridota rotifer). J Exp. Zool. 9, 497-516.

Conand, C., 1989. Les holothuries aspidochirotes du lagon de Nouvelle-Caledonie: biologie, écologie et exploitation. Universite de Bretagne Occidentale, Brest., l'ORSTOM, Paris.

Cuénot, L., 1891. Études morphologiques sur les Echinodermes. Arch. Biol. 11, 313-680.

Cuénot, L., 1948. Anatomie, éthologie et systématique des echinodermes. In: Grassé, P.-P. (Ed.), Traité de zoologie. Tome XI (Échinodermes - Stomocordés - Procordés). Masson, Paris, pp. 3-272. 
Darriba, D., Taboada, G.L., Doallo, R., Posada, D., 2012. jModelTest 2: more models, new heuristics and parallel computing. Nature Methods 9, 772.

Deichmann, E., 1930. The holothurians of the western part of the Atlantic Ocean. Bull. Mus. Comp. Zool. 71, 43-226.

Deichmann, E., 1940. Report on the holothurians, collected by the Harvard-Havana Expeditions 1938 and 1939, with a revision of the Molpadonia of the Atlantic Ocean. Mem. de la Sociedad Cubana de Hist. Nat. 14, 183-240.

Drummond, A.J., Ho, S.Y.W., Phillips, M.J., Rambaut, A., 2006. Relaxed phylogenetics and dating with confidence. PLoS Biol. 4, 699-710.

Ekman, S., 1925. Systematisch-phylogenetische Studien über Elasipoden und Aspidochiroten. Zool. Jahrb. Abt. Allg. Zool. Physiol. Tiere, 47, 430-540.

Farris, J.S., Albert, V.A., Källersjö, M., Lipscomb, D., Kluge, A.G., 1996. Parsimony jackknifing outperforms neighbor-joining. Cladistics. 12, 99-124.

Gallo, N.D., Cameron, J., Hardy, K., Fryer, P., Bartlett, D.H., Levin, L.A., 2015. Submersibleand lander-observed community patterns in the Mariana and New Britain trenches: Influence of productivity and depth on epibenthic and scavenging communities. Deep Sea Res. I 99, 119-133.

García-Arrarás, J.E., Greenberg, M.J., 2001. Visceral regeneration in holothurians. Microsc. Res. Tech. 55, 438-451.

Gebruk, A.V., 1990. Revision of Pelagothuriidae (Holothurioidea, Elasipoda) with a review of swimming holothurians. 2. A review of swimming holothurians and their origin. Zool. Zh. 69, 60-68.

Gilliland, P.M., 1992. Holothurians in the Blue Lias of southern Britain. Palaeont.. 35, 159-210.

Gilliland, P.M., 1993. The skeletal morphology, systematics and evolutionary history of holothurians. Palaeontological Association London. Spec. Pap. Palaeont. 47, 1-147.

Guensburg, T.E., Sprinkle, J., 2001. Earliest crinoids: New evidence for the origin of the dominant Paleozoic crinoids. Geology. 29, 131-134.

Haeckel, E., 1896. Systematische Phylogenie der wirbellosen Thiere (Invertebrata): Entwurf eines natürlichen Systems der Organismen auf Grund ihrer Stammesgeschichte. Georg Reimer, Berlin.

Hansen, B., 1956. Holothuroidea from depths exceeding 6000 meters. Scientific Results of the Danish Deep-Sea Expedition Round the World. Galathea Rep. 1950-1952 2, 33-54.

Hansen, B., 1975. Systematics and biology of the deep-sea holothurians. Part 1. Elasipoda. Galathea Rep. 13, 1-262.

Haude, R., 1992. Fossil holothurians: Sclerite aggregates as "good" species. In: Scalera-Liaci, L., Canicatti, C. (Eds.), Echinoderm Research 1991. A.A. Balkema, Rotterdam, pp. 29-33.

Haude, R., 1995. Echinodermen aus dem Unter-Devon der argentinischen Präkordillere. N. Jb. Geol. Paläont., Abh. 197, 37-86.

Haude, R., 2002. Origin of the holothurians (Echinodermata) derived by constructional morphology. Mitt. Mus. Naturkde. Berlin (Geowiss. Reihe) 5, 141-153.

Heding, S.G., 1935. Holothurioidea I. Apoda. Molpadioidea. Gephyrothurioidea. Danish IngolfExpedition 4, 1-84.

Heding, S.G., 1940. Die Holothurien der Deutschen Tiefsee-Expedition. II. - Aspidochirote und Elasipode Formen. In: Chun, C. (Ed.), Wissenschaftliche Ergebnisse der Deutschen Tiefsee-Expedition auf dem Dampfer "Valdivia" 1898-1899. Vol. 24. G. Fischer, Jena, pp. 317-375. 
Heding, S.G., 1950. Über die Planktothuria der Deutschen Tiefsee-Expedition, nebst einigen Bemerkungen uber die Systematik der pelagischen Holothurien. Zool. Anz. 145, 111118.

Hérouard, E., 1902. Holothuries provenant des campagnes de la Princesse-Alice (1892-1897). Resultats des Campagnes Prince Monaco Fasc. Imprimerie de Monaco.

Huxley, T.H., 1878. Anatomy of Invertebrated Animals. Murray, London.

Ishitani, Y., Ishikawa, S.A., Inagaki , Y., Tsuchiya, M., Takahashi, K., Takishita, K., 2011. Multigene phylogenetic analyses including diverse radiolarian species support the "Retaria" hypothesis-the sister relationship of Radiolaria and Foraminifera. Mar. Micropaleontol. 81, 32-42.

Jaeckle, W., Strathmann, R., 2013. The anus as a second mouth: anal suspension feeding by an oral deposit-feeding sea cucumber. Invert. Biol. 132, 62-68.

Jaeger, G.F., 1833. De Holothuriis. Gessner, Turici.

Jell, P.A., 2010. Late Silurian echinoderms from the Yass Basin, New South Wales-the earliest holothurian body fossil and two diploporitan cystoids (Sphaeronitidae and Holocystitidae). In: Holloway, D.J., Laurie, J.R. (Eds.), Siluro-Devonian Studies 1. Mem. . Australasian Palaeontologists 39, pp. 27-41.

Jell, P.A., 2014. A Tremadocian asterozoan from Tasmania and a late Llandovery edrioasteroid from Victoria. Alcheringa. 38, 528-540.

Kalinin, V.I., Silchenko, A.S., Avilov, S.A., Stonik, V.A., Smirnov, A.V., 2005. Sea cucumber triterpene glycosides, the recent progress in structural elucidation and chemotaxonomy. Phytochemistry Reviews. 4, 221-236.

Katoh, K., Standley, D.M., 2013. MAFFT multiple sequence alignment software version 7: improvements in performance and usability. Mol. Biol. Evol. 30, 772-780.

Kearse, M., Moir, R., Wilson, A., Stones-Havas, S., Cheung, M., Sturrock, S., Buxton, S., Cooper, A., Markowitz, S., Duran, C., Thierer, T., Ashton, B., Meintjes, P., Drummond, A., 2012. Geneious Basic: an integrated and extendable desktop software platform for the organization and analysis of sequence data. Bionformatics. 28, 1647-1649.

Kerr, A.M., 2001. Phylogeny of the apodan holothurians (Echinodermata) inferred from morphology. Zool. J. Linn. Soc. 133, 53-62.

Kerr, A.M., Kim, J., 1999. Bi-penta-bi-decaradial symmetry: a review of evolutionary and developmental trends in Holothuroidea (Echinodermata). J. Exp. Zool. 285, 93-103.

Kerr, A.M., Kim, J., 2001. Phylogeny of Holothuroidea (Echinodermata) inferred from morphology. Zool. J. Linn. Soc. 133, 63-81.

Kier, P.M., 1987. Class Echinoidea. Fossil Invertebrates. Blackwell, 596-611.

Kier, P.M., 1982. Rapid evolution in echinoids. Palaeont. 25, 1-9.

Kishino, H., Miyata, T., Hasegawa, M., 1990. Maximum likelihood inference of protein phylogeny and the origin of chloroplasts. J. Mol. Evol. 31, 15 l-160.

Koehler, R., Vaney, C., 1905. An account of the deep-sea Holothurioidea collected by the Royal Indian Marine Survey Ship Investigator. Order of the Trustees of the Indian Museum.

Kropp, R.K., 1982. Responses of five holothurian species to attacks by a predatory gastropod, Tonna perdix. Pac. Sci. 32, 445-452.

Lacey, K., McCormack, G., Keegan, B., Powell, R., 2005. Phylogenetic relationships within the class Holothuroidea, inferred from 18S rRNA gene data. Mar. Biol. 147, 1149-1154.

Lampert, K., 1885. Die Seewalzen. Holothurioidea. Eine systematische Monographie mit Bestimmungs- und Verbreitungs-Tabellen. In: Semper, C. (Ed.), Reisen im Archipel der 
Philippinen. Theil 2: Wissenschaftliche Resultate. Vol. 4, Part 3. CW Kreidel, Wiesbaden, pp. 1-310.

Lefebvre, B., Sumrall, C.D., Shroat-Lewis, R.A., Reich, M., Webster, G.D., Hunter, A.W., Nardin, E., Rozhnov, S.V., Guensburg, T.E., Touzeau, A., Noailles, F., Sprinkle, J., 2013. Palaeobiogeography of Ordovician echinoderms. In: Harper, D.A.T., Servais, T. (Eds.), Early Palaeozoic Biogeography and Palaeogeography. Geol. Soc. London Mem. 38, pp. 173-198.

Lewis, P.O., 2001. A likelihood approach to estimating phylogeny from discrete morphological character data. Syst. Biol. 50, 913-925.

Liang, D., Shen, X.X., Zhang, P., 2013. One thousand two hundred and ninety nuclear genes from a genome-wide survey support lungfishes as the sister group of tetrapods. Mol. Biol. Evol. 30, 1803-1807.

Littlewood, D.T., Smith, A.B., Clough, K.A., Emson, F.L., 1997. The interrelationships of the echinoderm classes: morphological and molecular evidence. Biol. J. Linn. Soc. 61, 409438.

Ludwig, H., 1889-1892. Echinodermen. Die Seewalzen. In: Bronn, H.G. (Ed.), Klassen und Ordnungen des Thier-Reichs, wissenschaftlich dargestellt in Wort und Bild. Vol. 2, Part 3 Echinodermen (Stachelhäuter) I. C. F. Winter'sche Verlagshandlung, Leipzig, pp. 1-460.

Ludwig, H., 1891. Ankyroderma musculus (Risso), eine Molpadiide des Mittelmeeres, nebst Bemerkungen zur Phylogenie und Systematik der Holothurien. Z. Wiss. Zool. 51, 569612.

Ludwig, H., 1894. The Holothurioidea. In: Reports on an exploration off the west coasts of Mexico, Central and South America, and off the Galapagos Islands, in charge of Alexander Agassiz, by the U.S. Fish Commission Steamer "Albatross," during 1891, Lieut. Commander Z. L. Tanner, U.S.N., commanding, Vol. xii. . Mem. of the Mus. of Comparative Zool. 17, 1-183.

MacBride, E.W., 1906. Echinodermata. In: Harmer, S.F., Shipley, A.E. (Eds.), The Cambridge Natural History, Vol. 1. MacMillan, London, pp. 425-623.

Maddison, D.R., Maddison, W.P., 2015. Mesquite: a modular system for evolutionary analysis. Version $3.04 \mathrm{http}: / /$ mesquiteproject.org.

Massin, C., 1987. Holothuries nouvelles et peu connues récoltées en Indonésie au cours de la Snellius-II Expedition. Bulletin de l'Institut Royal des Sciences Naturelles de Belgique, Biologie. 57, 97-121.

Michonneau, F., Paulay, G., 2014. Revision of the genus Phyrella (Holothuroidea: Dendrochirotida) with the description of a new species from Guam. Zootaxa. 3760, 101140.

Miller, J.E., Pawson, D.L., 1990. Swimming sea cucumbers (Echinodermata: Holothuroidea): a survey, with analysis of swimming behavior in four bathyal species. Smithsonian Contributions to Mar. Sci. 35, 1-18.

Miller, M.A., Pfeiffer, W., Schwartz, T., 2010. Creating the CIPRES Science Gateway for inference of large phylogenetic trees. 2010 Gateway Computing Environments Workshop (GCE). IEEE, pp. 1-8.

Mostler, H., Rahimi-Yazd, A., 1976. Neue Holothuriensklerite aus dem Oberperm von Julfa in Nordiran. Geol. Paläont. Mitt. Innsbruck 5, 1-35.

Müller, J., 1850. Anatomische Studien über die Echinodermen. Archiv für Anatomie und Physiologie. 1850, 117-155. 
O'Hara, T.D., Hugall, A.F., Thuy, B., Moussalli, A., 2014. Phylogenomic resolution of the class Ophiuroidea unlocks a global microfossil record. Curr. Biol. 24, 1874-1879.

O'Loughlin, P.M., Barmos, S., VandenSpiegel, D., 2011. The paracaudinid sea cucumbers of Australia and New Zealand (Echinodermata: Holothuroidea: Molpadida: Caudinidae). Mem. Mus. Vic. 68: 37-65.

O'Loughlin, P.M., 1998. A review of the holothurian family Gephyrothuriidae. In: Mooi, R., Telford, M. (Eds.), Echinoderms: San Francisco. A.A. Balkema, Rotterdam, pp. 493-498.

O'Loughlin, P.M., 2002. Report on selected species of BANZARE and ANARE Holothuroidea, with reviews of Meseres Ludwig and Heterocucumis Panning (Echinodermata). Mem. of Mus. Vic. 59, 297-325.

O'Loughlin, P.M., Ahearn, C., 2005. A review of pygal-furrowed Synallactidae (Echinodermata : Holothuroidea), with new species from the Antarctic, Atlantic and Pacific oceans. Mem. Mus. Vic. 62, 147-179.

O’Loughlin, P.M., Paulay, G., Davey, N., Michonneau, F., 2010. The Antarctic region as a marine biodiversity hotspot for echinoderms: Diversity and diversification of sea cucumbers. Deep-Sea Research II. 58, 264-275.

O’Loughlin, P.M., Skarbnik-López, J., Mackenzie, M., VandenSpiegel, D., 2015. Sea cucumbers of the Kerguelen Plateau, with descriptions of new genus and species (Echinodermata: Holothuroidea). Mem. Mus. Vic. 73, 59-93.

Östergren, H., 1897. Über die Function der ankerförmigen Kalkkörper der Seewalzen. Zool. Anz. 20, 148-159.

Östergren, H., 1907. Zur Phylogenie und Systematik der Seewalzen. In: Naturvetenskapliga Studentsällskapets i Uppsala, Z.s. (Ed.), Särtryck ur Zoologiska Studier tillägnade Professor T. Tullberg på hans 65-års dag. Almquist \& Wiksells BuchdruckereiAktiengesellschaft, Uppsala, pp. 191-215.

Ozsolak, F., Milos, P.M., 2010. RNA sequencing: advances, challenges, and opportunities. Nat. Rev. Genet. 12, 87-98.

Paul, C.R.C., Smith, A.B., 1984. The early radiation and phylogeny of echinoderms. Biol. Rev. Camb. 59, 443-481.

Paulay, G., Hansson, H., 2013. Holothuroidea. Accessed through: World Register of Marine Species at http://www.marinespecies.org/aphia.php?p=taxdetails\&id=123083.

Pawson, D.L., 1977. Molpadiid Sea Cucumbers (Echinodermata, Holothuroidea) of the Southern Atlantic, Pacific, and Indian Oceans. In: Pawson, D.L. (Ed.), Biology of the Antarctic Seas VI. American Geophysical Union, Washington, D.C., pp. 97-123.

Pawson, D.L., Fell, H.B., 1965. A revised classification of the dendrochirote holothurians. Breviora. 214, 1-7.

Pawson, D.L., Vance, D.J., Ahearn, C., 2001. Western Atlantic sea cucumbers of the order Molpadiida (Echinodermata: Holothuroidea). Bull. Biol. Soc. Wash. 10, 311-327.

Perrier, R., 1898. Sur les Holothuries recueillies par le Travailleur et le Talisman. Comptes rendus hebdomadaire des séances de l'Academie des Sciences, Paris 126, 1664-1666.

Perrier, R., 1902. Holothuries. In: Milne-Edwards, A. (Ed.), Expédition scientifique du "Travailleur" et du "Talisman" pendant les années 1880, 1881, 1882, 1883. Vol. VII Cirrhipèdes, Némertiens, Opistobranches, Holothuries. Masson, Paris, pp. 299-554.

Pisera, A., 1994. Echinoderms of the Mojcza Limestone. Palaeont. Pol. 53, 283-307.

Pleijel, F., Rouse, G.W., 2003. Ceci n'est pas une pipe: names, clades and phylogenetic nomenclature. J. Zool. Syst. Evol. Res. 41, 162-174. 
Purcell, S.W., Samyn, Y., Conand, C., 2012. Commercially important sea cucumbers of the world. FAO Species Catalogue for Fishery Purposes. FAO, Rome, p. 223.

Rambaut, A., Suchard, M.A., Xie, D., Drummond, A.J., 2013. Tracer v1.6. http://tree.bio.ed.ac.uk/software/tracer/.

Reich, A., Dunn, C., Akasaka, K., Wessel, G., 2015. Phylogenomic analyses of Echinodermata support the sister groups of Asterozoa and Echinozoa. PLoS ONE. 10, e0119627.

Reich, M., 2001. Ordovician holothurians from the Baltic Sea area. A.A. Balkema Publishers, Lisse.

Reich, M., 2004. Aspidochirote holothurians (Echinodermata) from the Middle Triassic of southern Germany. In: Heinzeller, T., Nebelsick, J.H. (Eds.), Echinoderms: München. A.A. Balkema Publishers, Leiden pp. 485-486.

Reich, M., 2010a. The early evolution and diversification of holothurians (Echinozoa). In: Harris, L.G., Böttger, S.A., Walker, C.W., Lesser, M.P. (Eds.), Echinoderms: Durham. Taylor \& Francis, London, pp. 55-59.

Reich, M., 2010b. Evolution and diversification of ophiocistioids (Echinodermata: Echinozoa). In: Harris, L.G., Böttger, S.A., Walker, C.W., Lesser, M.P. (Eds.), Echinoderms: Durham. Taylor \& Francis, London, pp. 51-54.

Reich, M., 2010c. The oldest synallactid sea cucumber (Echinodermata: Holothuroidea: Aspidochirotida). Paläont. Z. 84, 541-546.

Reich, M., 2013. How many species of fossil holothurians are there? In: Johnson, C. (Ed.), Echinoderms in a Changing World. Proceedings of the 13th International Echinoderm Conference, University of Tasmania. Taylor \& Francis, London, pp. 23-51.

Reich, M., 2015. Different pathways in early evolution of the holothurian calcareous ring? In: Zamora, S., Rábano, I. (Eds.), Progress in echinoderm palaeobiology. Cuadernos del Museo Geominero. 19, pp. 137-145.

Reich, M., Haude, R., 2004. Ophiocistioidea (fossil Echinodermata): an overview. In: Heinzeller, T., Nebelsick, J.H. (Eds.), Echinoderms: München. A.A. Balkema Publishers, Leiden, pp. 489-494.

Reich, M., Kutscher, M., 2014. A new ophiocistioid (Echinodermata) from the Silurian of Gotland, Sweden. GFF. 136, 459-463.

Reich, M., O'Loughlin, P.M., 2010. Modern holothurian calcareous ring anatomy and stereom structure-the need for more detailed studies and research. In: Reich, M., Reitner, J., Roden, V., Thuy, B. (Eds.), Echinoderm Research 2010. 7th European Conference on Echinoderms, Göttingen. Göttingen University Press, Göttingen, pp. 88-89.

Reich, M., Smith, A.B., 2011. A new elasipodid holothurian representative from the early Devonian Hunsrück slate fossil lagerstätte, Germany. Gulf of Mexico Sci. 29, 153.

Rhoads, D.C., Morse, J.W., 1971. Evolutionary and ecologic significance of oxygen-deficient marine basins. Lethaia 4, 413-428.

Roberts, D., Bryce, C., 1982. Further observations on tentacular feeding mechanisms in holothurians. J. Exp. Mar. Biol. Ecol. 59, 151-163.

Roberts, D., Moore, H.M., 1997. Tentacular diversity in deep-sea deposit-feeding holothurians: implications for biodiversity in the deep sea. Biodivers. Conserv. 6, 1487-1505.

Robison, B.H., 1992. Bioluminescence in the benthopelagic holothurian Enypniastes eximia. J. Mar. Biol. Assoc. U.K. 72, 463-472.

Ronquist, F., Huelsenbeck, J.P., 2003. MrBayes 3: Bayesian phylogenetic inference under mixed models. Bioinformatics. 19, 1572-1574. 
Samyn, Y., 2003. Towards an understanding of the shallow-water holothuroid fauna (Echinodermata: Holothuroidea) of the western Indian Ocean. Vrije Universiteit Brussels, Brussels, p. 384.

Seilacher, A., 1961. Holothurien im Hunsrückschiefer (Unter-Devon). Notizbl Hess L.-A. Bodenforsch. Wiesbaden 89, 66-72.

Selenka, E., 1867. Beiträge zur Anatomie und Systematik der Holothurien. Göttingen, Leipzig. Z. Wiss. Zool. 17, 291-374.

Semon, R., 1888. Die Entwicklung der Synapta digitata und ihre Bedeutnug für die Phylogenie der Echinodermen. Jenaische Z. Naturwiss. 22, 175-309.

Semper, C., 1867-8. Holothurien. In: Semper, C. (Ed.), Reisen im Archipel der Philippinen. Zweiter Theil. Wissenschaftliche Resultate. Erster Band. W. Engelmann, Leipzig, p. 288.

Shick, J.M., 1983. Respiratory gas exchange in echinoderms. In: Jangoux, M., Lawrence, J.M. (Eds.), Echinoderm Studies. Vol. 1. A.A. Balkema, Rotterdam, pp. 67-110.

Shimodaira, H., 2002. An approximately unbiased test of phylogenetic tree selection. Syst. Biol. 51, 492-508.

Silchenko, A.S., Avilov, S.A., Kalinin, V.I., Kalinovsky, A.I., Stonik, V.A., Smirnov, A.V., 2004. Pseudostichoposide B-New triterpene glycoside with unprecedent type of sulfatation from the deep-water North-Pacific sea cucumber Pseudostichopus trachus. Nat. Prod. Res. 18, 565-570.

Silvestro, D., Michalak, I., 2012. raxmlGUI: a graphical front-end for RAxML. Org. Divers Evol. 12, 335-337.

Sluiter, C.P., 1901a. Die Holothurien der Siboga-Expedition. In: Weber, M. (Ed.), Siboga Expeditie Vol. 44. E. J. Brill, Leiden, pp. 1-141.

Sluiter, C.P., 1901b. Neue Holothurien aus der Tiefsee des Indischen Archipels gesammelt durch die Siboga-Expedition. Tijdschrift der Nederlandsche Dierkundige Vereeniging. 2, 48-50.

Smirnov, A.V., 1998. On the classification of the apodid holothurians. In: Mooi, R., Telford, M. (Eds.), Echinoderms: San Francisco. A.A. Balkema, Rotterdam, pp. 517-522.

Smirnov, A.V., 2012. System of the class Holothuroidea. Paleontol. J. 46, 793-832.

Smirnov, A.V., 2015. Paedomorphosis and heterochrony in the origin and evolution of the class Holothuroidea. Paleontol. J. 49, 1597-1615.

Smirnov, A.V., 2016. Parallelisms in the evolution of sea cucumbers (Echinodermata: Holothuroidea). Paleontol. J. 50, 1610-1625.

Smith, A.B., 1997. Echinoderm larvae and phylogeny. Annu Rev Ecol Syst 28, 219-241.

Smith, A.B., 2005. The pre-radial history of echinoderms. Geological. J. 40, 255-280.

Smith, A.B., Reich, M., 2013. Tracing the evolution of the holothurian body plan through stemgroup fossils. Biol. J. Linn. Soc. 109, 670-681.

Smith, A.B., Reich, M., Zamora, S., 2013. Comment on supposed holothurian body fossils from the middle Ordovician of Wales (Botting and Muir, Palaeontologia Electronica: 15.1.9A). Palaeontol. Electron. 16(1), 1-5.

Solís-Marín, F.A., 2003. Systematics and Phylogeny of the Holothurian Family Synallactidae. University of Southampton, Southampton.

Speckmann, P., 1968. Holothurien-Sklerite aus der Mittel-Trias der Ostalpen. Mitt Bayer Staatssamml Palaeontol. Hist. Geol. 8, 197-218.

Stamatakis, A., 2014. RAxML Version 8: A tool for phylogenetic analysis and post-analysis of large phylogenies. Bioinformatics. 30, 1312-1313. 
Stanley, S.M., 1977. Trends, rates, and patterns of evolution in the Bivalvia. Dev. Palaeontol. Stratigr. 5, 209-250.

Sumrall, C.D., Wray, G.A., 2007. Ontogeny in the fossil record: diversification of body plans and the evolution of "aberrant" symmetry in Paleozoic echinoderms. Paleobiol. 33, 149163.

Sun, J., Zhang, L., Pan, Y., Lin, C., Wang, F., Kan, R., Yang, H., 2015. Feeding behavior and digestive physiology in sea cucumber Apostichopus japonicus. Physiol Behav 139, 336343.

Swofford, D.L., 2002. PAUP*. Phylogenetic Analysis Using Parsimony (*and Other Methods). Version 4. Sinauer Associates, Sunderland, Massachusetts.

Talavera, G., Castresana, J., 2007. Improvement of phylogenies after removing divergent and ambiguously aligned blocks from protein sequence alignments. Syst Biol 56, 564-577.

Telford, M.J., Lowe, C.J., Cameron, C.B., Ortega-Martinez, O., Aronowicz, J., Oliveri, P., Copley, R.R., 2014. Phylogenomic analysis of echinoderm class relationships supports Asterozoa. Proc. Royal Soc. B. 281, 20140479.

Théel, H., 1882. Report on the Holothurioidea, dredged by H.M.S. 'Challenger' during the years 1873-76. Part I. Challenger Reports Zoology. 13, 1-176.

Théel, H., 1886. Report on the Holothurioidea dredged by H.M.S. 'Challenger' during the years 1873-76. Part II. Challenger Reports Zoology. 39, 1-290.

Théel, H., Hjalmar, J., 1879. Preliminary Report on the Holothuridae of the Exploring Voyage of HMS 'Challenger' under Professor Sir C. Wyville Thomson. Part. I. Bih. K. Svenska Vet. Akad. Handl. 5.

Vermeij, G.J., 1977. The Mesozoic marine revolution: evidence from snails, predators and grazers. Paleobiol. 3, 245-258.

Xia, X., Xie, Z., 2001. DAMBE: Software Package for Data Analysis in Molecular Biology and Evolution. J. Hered. 92, 371-373.

Xia, X., Xie, Z., Salemi, M., Chen, L., Wang, Y., 2003. An index of substitution saturation and its application. Mol. Phylogenet. Evol. 26, 1-7.

Zamora, S., Lefebvre, B., Álvaro, J.J., Clausen, S., Elicki, O., Fatka, O., Jell, P., Kouchinsky, A., Lin, J.-P., Nardin, E., 2013. Cambrian echinoderm diversity and palaeobiogeography. In: Harper, D.A.T., Servais, T. (Eds.), Early Palaeozoic Biogeography and Palaeogeography. Geol. Soc. London Mem. 38, pp. 157-171.

Zamora, S., Rahman, I.A., 2014. Deciphering the early evolution of echinoderms with Cambrian fossils. Palaeont. 57, 1105-1119.

Zamora, S., Rahman, I.A., Smith, A.B., 2012. Plated Cambrian bilaterians reveal the earliest stages of echinoderm evolution. PLoS ONE. 7, e38296. 


\subsection{Appendix A}

\section{A.1 Family diagnoses}

Diagnoses for three families within the clade Persiculida. Apomorphies for the below families are indicated by italics.

Clade Persiculida: Posterior vertical furrow present. Body wall ossicles absent.

Remarks: No formal rank is assigned to Persiculida here. The clade contains three familes:

Gephyrothuriidae, Molpadiodemidae fam. nov., and Pseudostichopodidae fam. nov.

Gephyrothuriidae was place as sister group to Molpadiodemidae in the current phylogenetic

analyses, though the node was poorly supported. Other genera (e.g., Hadalothuria, Benthothuria, Hansenothuria, and Meseres) possibly belong within this clade and might be added to these families when more data become available for them.

Family Gephyrothuriidae (Koehler and Vaney, 1905)

Diagnosis: Persiculida (above) characterized by: cylindrical body with rounded terminal ends; body surface covered in numerous scattered small papillae and tube feet that give the body surface a granular look, tube feet are concentrated towards the anterior and posterior ends; tube feet and papillae are more prominent closer to radials; long (4-10mm) filiform papillae present; tentacle ampullae and retractor muscles absent; large often 16-20 digitate or digitate-cupped tentacles, one polian vesicle; respiratory trees with two branches and connect at a common base; longitudinal muscles undivided; gonad tubules on both sides of dorsal mesentery; calcareous ring comprised of 10 thick plates, radial plates of the calcareous ring possess an anteriorly opening central hole or notch, radial and interradial plates largely uniform in size.

Type genus: Gephyrothuria (Koehler and Vaney, 1905)

Type species: Gephyrothuria alcocki (Koehler and Vaney, 1905)

Other included species: Paroriza prouhoi (Hérouard, 1902)

Remarks: Koehler and Vaney (1905) erected Gephyrothuriidae for their monotypic genus Gephyrothuria. Since then, the placement of the family within Holothuroidea has been greatly debated (see O'Loughlin, 1998). Most recently, Smirnov (2012) resurrected Heding's (1935) order Gephyrothuriida and placed Gephyrothuriidae (containing Gephyrothuria and 
Hadalothuria) within it. Our phylogenetic results (main text Fig. 3) support the close relationship of Gephyrothuria with Paroriza within Persiculida, thus we reassign Paroriza to Gephyrothuriidae and place it within Persiculida here. Interestingly, Massin (1987) also placed Paroriza in Gephyrothuridae (Koehler and Vaney, 1905) after analyzing the general anatomy of his new Paroriza verrucosa specimens. We also remove Hadalothuria (Hansen, 1956) from Gephyrothuriidae until more data become available for it and it can be reassigned confidently.

\section{References:}

Koehler and Vaney (1905) p. 78; Heding (1935) p. 77; Massin (1987) pp. 116-118; O’Loughlin (1998) pp. 493-497; Smirnov (2012) p. 825

Family Molpadiodemidae fam. nov., Miller et al., 2017

Diagnosis: Persiculida (above) characterized primarily by the characters diagnosed by O'Loughlin and Ahearn (2005) for the Molpadiodemas: cylindrical body with rounded terminal ends; body surface covered in small discrete tube feet; large prominent tube feet and papillae absent from the paired radii; tentacle ampullae and retractor muscles absent; often 18-20 peltate tentacles; one large ventral polian vesicle; respiratory trees comprised of two unequal clustered branches connected at a common base near the cloaca; longitudinal muscles are undivided and sit flat against the inner body wall; gonad tubules branch out from a common gonoduct base and are positioned posteriorly on each side of the dorsal mesentery; calcareous ring comprised of 10 thick plates; radial plates of the calcareous ring possess an anteriorly opening central hole or notch, and have two pairs of posterior "teeth" or protrusions; interradial plates of the calcareous ring are set lower than the radial plates and have one large anterior tooth and a smooth concaved posterior surface; ossicles are not found in the body walls or tube feet; branched rod ossicles can be present in tentacles of which the side branches and terminals commonly collide to form networks; body surface sometimes inhabited by epibionts that can occasionally cause dermal cavities.

Type genus: Molpadiodemas (Heding, 1935)

Type species: Molpadiodemas atlanticus (Perrier, 1898)

Other included species: Molpadiodemas villosus Théel, 1886 and Molpadiodemas involutus (Sluiter, 1901b) 


\section{Remarks:}

Heding (1935) suggested that his newly erected genus, Molpadiodemas, seemed closely related to Gephyrothuria, but that there were such great differences that they must be a separate genus. He later decided to group them both in his family Gephyrothuridae (Heding, 1940). O'Loughlin and Ahearn (2005) completed a thorough rediagnosis of Molpadiodemas and made Platystichopus (Heding, 1940) a junior synonym. Our phylogenetic results (main text Fig. 3) agree with Heding's (1935) idea of a close relationship between Molpadiodemas and Gephyrothuria, though we recovered Paroriza as closest to Gephyrothuria. We combine O’Loughlin and Ahearn's (2005) key morphological characters for Molpadiodemas (body surface covered with small tubefeet, tube feet and papillae missing from the paired radii, branched gonad tubules arise from a common base, longitudinal muscles are fixed flat to the body wall, and ossicles not found in tube feet) with our molecular evidence and place Molpadiodemas (sensu O'Loughlin and Ahearn, 2005) in its own family within Persiculida. References:

Heding, (1935) pp. 77-80; Heding, (1940) pp. 356-357; Deichmann, (1940) pp. 208-211; O’Loughlin (1998) p. 497; O’Loughlin (2002) pp. 303-315; O’Loughlin and Ahearn, (2005) pp. 149-153.

Family Pseudostichopodidae fam. nov., Miller et al., 2017

Diagnosis: Persiculida (above) characterized mainly by the genus, Pseudostichopus, diagnosis of O’Loughlin and Ahearn (2005): cylindrical body with rounded terminal ends; large prominent tubefeet or papillae are positioned along the paired radii; tentacle ampullae and retractor muscles absent; often 18-20 peltate tentacles; one polian vesicle is ventrally positioned; respiratory trees comprised of two unequal clustered branches connected at a common base near the cloaca; longitudinal muscles are round in shape and protrude slightly from the inner body wall; gonad tubules branch separately from the gonoduct (not from a common base) and are positioned on each side of the dorsal mesentery; the calcareous ring is comprised of 10 thick plates; radial plates of the calcareous ring possess an anteriorly opening central hole or notch, and have two pairs of posterior "teeth" or protrusions; interradial plates of the calcareous ring are set lower than the radial plates and have one large anterior tooth and a smooth concaved posterior surface; ossicles are sometimes found in papillae and tube feet; rod ossicles can be 
present in tentacles and are often unbranched; body surface often inhabited by epibionts or covered by hard debris (e.g., sponge spicules and forams).

Type genus: Pseudostichopus (Théel, 1886)

Type species: Pseudostichopus mollis (Théel, 1886)

Remarks: Théel (1886) erected Pseudostichopus for Pseudostichopus mollis (Théel, 1886) and Pseudostichopus villosus (Théel, 1886), though the latter is now accepted as Molpadiodemas villosus. O'Loughlin and Ahearn (2005) rediagnosed the genus with a clear set of morphological characters and placed it within Synallactidae. Our phylogenetic results (main text Fig. 3) recovered Pseudostichopus as the sister group to Molpadiodemas and Gephyrothuria + Paroriza within Persiculida but with low support. Here we consider O'Loughlin and Ahearn's (2005) key morphological characters for Pseudostichopus (tube feet and papillae often on the paired radii, non-branched gonad tubules arise singularly in a line from the gonoduct, longitudinal muscles are convexly fixed to the body wall, and ossicles are sometimes found in tube feet and papillae) with our molecular evidence and place Pseudostichopus (sensu O'Loughlin and Ahearn, 2005) in its own family within Persiculida.

\section{References:}

Théel, (1886) p. 169; Massin, (1987) pp. 116-118; O'Loughlin and Ahearn, (2005) pp. 149-169. 


\section{Figure legends}

Fig. 1. Morphological diversity of Holothuroidea. (A) Pelagothuria natatrix. Photo (C D.L. Pawson. (B) Ypsilothuria cf. bitentaculata. Photo (C) G.W. Rouse. (C) Paracaudina chilensis. Photo () G. Paulay. (D) Lissothuria nutriens. Photo (C G.W. Rouse. (E) Enypniastes eximia. Photo (C) G. Paulay. (F) Colochirus robustus. Photo (C) A.K. Miller.

Fig. 2. Previous hypotheses of extant holothuroid phylogenetic relationships. (A) Semper (18678). (B) Ludwig (1889-1892). (C) Haeckel (1896). (D) Perrier (1902). (E) MacBride (1906). (F) Östergren (1907). (G) Becher (1909). (H) Cuénot (1948). (I) Phylogenetic interpretation of Pawson and Fell's (1965) Linnaean classification. (J) Haude (1992). (K) Smith's (1997) interpretation of data from Littlewood et al. (1997). (L) Kerr and Kim (2001). (M) Lacey et al. (2005). (N) Reich (2010a). (O) Phylogenetic interpretation of Smirnov 's (2012) system. Taxon designations are from Pawson and Fell (1965) and asterisks (*) indicate alternative positions of Molpadida.

Fig. 3. Maximum likelihood (ML, lnL - 50494.61) and Bayesian Inference (BI, lnL - 48725) tree inferred from the concatenated six-gene dataset (reduced dataset, nine partitions). Symbols adjacent to nodes refer to ML bootstrap scores (BS), BI posterior probability (PP), and maximum parsimony (MP) parsimony jackknife (JK) majority rule consensus tree values in that order (BS/PP/JK). Branch lengths for the outgroup terminals and the ingroup were shortened (//) for clarity. A space ( ) indicates BS or JK values $<50 \%$ or PP values $<0.70$. A hyphen (-) indicates that a node was not found in the respective analysis. An asterisk (*) indicates a node value with BS or JK $>90$ and PP $>0.95$. Colored boxes surround members of Pawson and Fell's (1965) orders: yellow $=$ Apodida; purple $=$ Elasipodida $;$ green $=$ Aspidochirotida ; red $=$ Molpadida; blue $=$ Dendrochirotida; and orange $=$ Dactylochirotida .

Fig. 4. Summary of holothuroid relationships based on BI and ML analyses of the reduced dataset with the clade and group names proposed in this study. Only nodes with $>50 \% \mathrm{BS}$ maximum likelihood values are shown. Asterisks $(*)$ indicate that the type taxon of the indicated family is present within the group and roman numerals (I, II, or III) indicate that a paraphyletic or polyphyletic family group may require a new name. Of these roman numeral groups the non- 
monophyly of Laetmogonidae and Synaptidae was not significantly supported by AU tests (Shimodaira, 2002). The number one [1] distinguishes genera (Bathyplotes and Paelopatides) newly placed within Stichopodidae. The number two [2] distinguishes a new genus (Paroriza) within Gephyrothuriidae. The two newly erected families (Molpadiodemidae and Pseudostichopodidae) are in bold. The colored boxes surround members of the large groups recovered by the current study.

Fig. 5. Chronogram of Holothuroidea. Three nodes (green circles with letters A-C) were used as fossil-based time constraints (refer to text and Table 2). Estimated mean divergence times are listed adjacent to the nodes. Purple lines through nodes represent the $95 \%$ confidence interval for the dates. Tree branch colors (following color spectrum located in the top left corner) represent the relative rate of overall substitutions per site per million years; brown branches represent the slowest rates, green intermediate, and purple represent the fastest. The dark blue bars underneath the stratigraphic divisions indicate 'species'-level diversity of Holothuroidea through time (based on Reich, 2013).

Fig. 6. Chronogram of Holothuroidea. Six nodes (green circles with letters A-F) were used as fossil-based time constraints (refer to text and Table 2). Estimated mean divergence times are listed adjacent to the nodes. Purple lines through nodes represent the $95 \%$ confidence interval for the dates. Tree branch colors (following color spectrum located in the top left corner) represent the relative rate of overall substitutions per site per million years; brown branches represent the slowest rates, green intermediate, and pink represent the fastest. The dark blue bars underneath the stratigraphic divisions indicate species 'species'-level diversity of Holothuroidea through time (based on Reich, 2013).

Fig. 7. Maximum likelihood transformations for (A) respiratory trees (B) body wall skeletal elements excluding table ossicles (C) table ossicles and (D) tentacle shape. Numbers adjacent to nodes refer to proportional likelihood estimations. Multiple scores, if present, are separated by a forward slash and listed in order of most likely states. An asterisk (*) indicates that a node has an estimated proportional likelihood of $>95 \%$. A “(c)" indicates that a terminal is part of a complex. The colored boxes around the clades represent the large clades recovered by the current study 
(refer to text and Fig. 4). 
Table 1. Voucher information and GenBank accession numbers for specimens used in the molecular analyses. New sequences are in bold. An exclamation mark (!) indicates the taxon was identified to genus by DNA. Depositories: SIO-BIC, Scripps Institution of Oceanography Benthic Invertebrate Collection; UF, Florida Museum of Natural History Invertebrate Zoology Collection; NMV, Museum Victoria Marine Invertebrates Collection; MNHN, Muséum National d'Histoire Naturelle; NIWA, National Institute of Water and Atmospheric Research; NOCS-DC, National Oceanography Center, Southampton, Discovery Collection; MZB, Museum Zoologicum Bogoriense; KSORC, Korea South Pacific

Ocean Research Center. One asterisk (*) denotes that only a subsample voucher exists. Two asterisks (**) denotes that another specimen, NOCS-DC $13369 \# 1$, is from a nearby station on the same cruise.

\begin{tabular}{|c|c|c|c|c|c|c|c|c|}
\hline Taxa & Location & Voucher & $18 S$ & $16 S$ & CO1 & H3 & $12 S$ & $28 S$ \\
\hline Abyssocucumis abyssorum & USA, California & SIO-BIC E5610 & KX856836 & KX856767 & KX874335 & KX874442 & KX856686 & \\
\hline Acaudina molpadioides & Australia, West Coast & NMV-MIC F112144 & KX856820 & KX856743 & KX874336 & KX874455 & KX856677 & KX856891 \\
\hline Actinopyga varians & Micronesia, Chuuk State & KSORC 0315 & KX856851 & KX856787 & KX874345 & KX874409 & & \\
\hline Afrocucumis africana & Mariana Islands, Guam & SIO-BIC E6844 & KX856841 & KX856780 & KX874348 & KX874451 & & KX856908 \\
\hline Amperima robusta & Antarctica & NIWA 37990 & KX856798 & KX856728 & KX874381 & KX874457 & KX856702 & \\
\hline Apostichopus californicus & varies & varies & DQ777084 & DQ777096 & HM542319 & & & DQ777087 \\
\hline Apostichopus parvimensis & USA, California & no voucher & KX856808 & KX856750 & KX874373 & KX874417 & KX856666 & \\
\hline Aslia pygmaea & USA, Florida & SIO-BIC E6812 & KX856838 & KX856774 & KX874339 & KX874450 & KX856685 & DQ777091 \\
\hline Astichopus multifidus & USA, Florida & FLMNH-IZC 3985 & KX856809 & KX856753 & KX874376 & KX874422 & KX856665 & \\
\hline Bathyplotes sp. 1 & Antarctica & SIO-BIC E5111 & KX856812 & KX856748 & KX874358 & KX874415 & KX856667 & KX856881 \\
\hline Bathyplotes sp. 2 & North Scotia Ridge & SIO-BIC E6356 & KX856802 & KX856747 & KX874357 & KX874416 & KX856668 & KX856882 \\
\hline Benthogone abstrusa & Australia, NW Coast & NMV-MIC F146599 & KX856795 & KX856733 & KX874374 & KX874466 & & KX856874 \\
\hline Bohadschia koellikeri & Indonesia/Australia & No Voucher & KX856852 & KX856785 & JX683894 & KX874411 & & \\
\hline Chiridota albatrossii complex 1 & USA, California & SIO-BIC E5611 & KX856859 & KX856788 & KX874397 & KX874471 & KX856718 & KX856870 \\
\hline Chiridota albatrossii complex 2 & USA, California & SIO-BIC E5612 & KX856860 & & KX874398 & KX874472 & KX856717 & \\
\hline Chiridota laevis & Greenland & SIO-BIC E5602 & KX856858 & & KX874399 & KX874473 & KX856719 & \\
\hline Chiridota rigida & Mariana Islands, Guam & SIO-BIC E6841 & KX856857 & & KX874401 & KX874469 & KX856721 & KX856868 \\
\hline Colochirus robustus & Indonesia, Raja Ampat & SIO-BIC E6626 & KX856832 & KX856781 & KX874347 & & KX856695 & \\
\hline Crucella scotiae 1 & Scotia Arc & SIO-BIC E5296 & KX856829 & KX856761 & KX874366 & KX874433 & & KX856901 \\
\hline Crucella scotiae 2 & Antarctica & NMV-MIC F193785 & KX856826 & KX856760 & KX874367 & KX8744334 & KX856690 & KX856897 \\
\hline
\end{tabular}




\begin{tabular}{|c|c|c|c|c|c|c|c|c|}
\hline Taxa & Location & Voucher & $18 S$ & $16 \mathrm{~S}$ & CO1 & H3 & $12 S$ & $28 \mathrm{~S}$ \\
\hline Cucumaria miniata & varies & varies & DQ777082 & & HM542157 & & & DQ777092 \\
\hline Deima validum & Northeast Atlantic & Lost** & KX856815 & KX856744 & KX874364 & KX874426 & KX856679 & \\
\hline Echinocucumis hispida & Antarctica & NIWA 37845 & KX856835 & & KX874396 & KX874438 & & \\
\hline Echinocucumis cf. hispida & Antarctica & SIO-BIC E6674 & KX856833 & KX856779 & KX874395 & KX874437 & KX856714 & KX856899 \\
\hline Enypniastes eximia & New Zealand & SIO-BIC E6670 & KX856792 & KX856730 & KX874383 & KX874465 & KX856708 & KX856875 \\
\hline Euapta tahitiensis & Micronesia, Chuuk State & KSORC 0253 & KX856861 & & KX874402 & KX874475 & KX856723 & KX856869 \\
\hline Euthyonidiella huwi & Antarctica & SIO-BIC E5709 & KX856840 & KX856782 & KX874371 & KX874448 & KX856698 & KX856910 \\
\hline Gephyrothuria alcocki & New Zealand & NIWA 45733 & KX856856 & KX856738 & KX874377 & KX874406 & KX856671 & KX856893 \\
\hline Heteromolpadia tridens & Australia, West Coast & NMV-MIC F112138 & KX856823 & KX856740 & KX874362 & KX874431 & KX856673 & KX856890 \\
\hline Heterothyone alba & New Zealand & SIO-BIC E6666 & KX856831 & KX856765 & KX874390 & KX874444 & KX856693 & KX856898 \\
\hline Holothuria hilla & Mariana Islands, Guam & SIO-BIC E6842 & KX856854 & KX856783 & KX874337 & KX874407 & KX856663 & KX856892 \\
\hline Holothuria leucospilota & varies & varies & AY133472 & AY338419 & FJ971394 & & DQ777101 & DQ777093 \\
\hline Isostichopus badionotus & USA, Florida & FLMNH-IZC 4703 & KX856819 & KX856756 & KX874354 & KX874425 & & \\
\hline Labidodemas cf. pertinax & Mariana Islands, Guam & No Voucher & KX856850 & KX856784 & KX874338 & KX874408 & & \\
\hline Leptosynapta clarki & USA, Massachusetts & SIO-BIC E6815 & KX856864 & & HM542252 & KX874476 & & KX856872 \\
\hline Lissothuria nutriens & USA, California & SIO-BIC E6675 & KX856845 & KX856775 & KX874341 & KX874443 & KX856700 & \\
\hline Massinium magnum & Papua New Guinea & FLMNH-IZC 14866 & KX856849 & KX856778 & KX874351 & KX874467 & & \\
\hline Mesothuria oktaknemus & French Polynesia & FMNH-IZC 9746 & KX856824 & KX856734 & KX874394 & KX874429 & KX856710 & KX856894 \\
\hline Molpadia arenicola & USA, California & SIO-BIC E6830 & KX856821 & KX856741 & KX874344 & KX874413 & KX856676 & KX856895 \\
\hline Molpadia musculus complex & Antarctica & SIO-BIC E5295 & KX856816 & KX856739 & KX874386 & KX874412 & KX856674 & KX856889 \\
\hline Molpadiodemas involutus & South Pacific Ocean & NIWA 49857 & KX856801 & KX856736 & HM196530 & KX874404 & & KX856878 \\
\hline Molpadiodemas villosus & varies & varies & DQ777086 & DQ777098 & AF486436 & KY019184 & & DQ777088 \\
\hline Myriotrochus antarcticus & Antarctica & NMV-MIC F168643 & KX856866 & & & & & \\
\hline Myriotrochus sp. & Antarctica & NIWA 37812 & KX856865 & KX856789 & KX874403 & KX874468 & & KX856867 \\
\hline
\end{tabular}




\begin{tabular}{|c|c|c|c|c|c|c|c|c|}
\hline Taxa & Location & Voucher & $18 S$ & $16 S$ & CO1 & H3 & $12 S$ & $28 S$ \\
\hline Oneirophanta setigera & French Polynesia & FMNH-IZC 9706 & KX856813 & KX856745 & KX874363 & KX874427 & & KX856885 \\
\hline Orphnurgus glaber & Australia, NW Coast & NMV-MIC F146594 & KX856814 & KX856746 & KX874361 & KX874428 & KX8566678 & KX856883 \\
\hline Pachythyone rubra & USA, California & SIO-BIC E6676 & KX856847 & KX856770 & KX874387 & KX874446 & KX856684 & \\
\hline Paelopatides sp. 1 ! & USA, California & SIO-BIC E4365 & KX856806 & KX856757 & KX874356 & KX874418 & KX856670 & KX856884 \\
\hline Paelopatides sp. 2 & Mexico, Gulf of California & SIO-BIC E5609 & KX856807 & & KX874355 & KX874419 & KX856669 & \\
\hline Pannychia cf. moseleyi & USA, California & SIO-BIC E5614 & KX856794 & KX856732 & KX874379 & KX874464 & KX856706 & KX856876 \\
\hline Pannychia moseleyi & USA, California & SIO-BIC E4625 & KX856793 & KX856731 & KX874380 & KX874463 & KX856707 & \\
\hline Paracaudina chilensis & USA, Oregon & FLMNH-IZC 11429 & KX856822 & KX856742 & KX874343 & KX874414 & KX856675 & \\
\hline Paracucumis turricata & Antarctica & NMV-MIC F169314 & KX856828 & KX856762 & KX874368 & KX874439 & KX856691 & KX856902 \\
\hline Paradota sp. & Antarctica & SIO-BIC E5604 & KX856862 & & KX874400 & KX874470 & KX856722 & \\
\hline Parastichopus tremulus & Norway & FLMNH-IZC 4863 & KX856804 & KX856752 & KX874359 & & & \\
\hline Paroriza prouhoi & Northeast Atlantic & NOCS-DC 13369\#2 & KX856855 & KX856737 & KX874378 & KX874405 & KX856672 & \\
\hline Pearsonothuria graeffei & Indonesia, Raja Ampat & Donated to MZB & KX856853 & KX856786 & EU848285 & KX874410 & AY574860 & \\
\hline Peniagone diaphana & Northeast Atlantic & NOCS-DC 13369\#2 & KX856800 & KX856725 & KX874384 & KX874459 & KX856705 & \\
\hline Peniagone sp. & Mexico, Gulf of California & SIO-BIC E5608 & KX856799 & KX856726 & KX874385 & KX874460 & KX856704 & KX856877 \\
\hline Pentactella leonina & Chile & SIO-BIC E6672 & KX856846 & KX856768 & KX874369 & KX874440 & KX856699 & KX856906 \\
\hline Pentactella sp. & Burdwood Bank East & SIO-BIC E6671 & KX856834 & KX856769 & KX874372 & KX874441 & KX856687 & KX856903 \\
\hline Pentamera calcigera & Greenland & SIO-BIC E5613 & KX856843 & KX856773 & & KX874452 & KX856688 & KX856905 \\
\hline Phyrella mookiei & Mariana Islands, Guam & FLMNH-IZC 10336 & KX856842 & KX856777 & KX874346 & KX874477 & KX856711 & KX856909 \\
\hline Placothuria squamata & New Zealand & SIO-BIC E6668 & & & KX874391 & KX874445 & KX856692 & \\
\hline Protelpidia murrayi & Antarctica & SIO-BIC E5110 & KX856796 & KX856727 & KX874382 & KX874456 & KX856703 & \\
\hline Pseudostichopus sp. 1 & Antarctica & SIO-BIC E6363 & KX856811 & KX856758 & KX874388 & KX874453 & KX856715 & KX856880 \\
\hline Pseudostichopus sp. 2 & Antarctica & SIO-BIC E5708 & KX856810 & KX856759 & KX874389 & KX874454 & KX856716 & KX856879 \\
\hline Psolidium dorsipes & Antarctica & SIO-BIC E6673 & KX856837 & KX856766 & KX874350 & KX874435 & KX856694 & KX856900 \\
\hline
\end{tabular}




\begin{tabular}{|c|c|c|c|c|c|c|c|c|}
\hline Taxa & Location & Voucher & $18 S$ & $16 S$ & CO1 & H3 & $12 S$ & $28 S$ \\
\hline Psolidium whittakeri & Antarctica & SIO-BIC E5136 & KX856827 & KX856763 & KX874349 & KX874432 & KX856689 & \\
\hline Psycheotrephes exigua & Antarctica & NIWA 39018 & KX856791 & & KX874392 & KX874462 & KX856712 & KX856873 \\
\hline Psychropotes longicauda & USA, California & SIO-BIC E4074 & KX856790 & KX856724 & & KX874461 & KX856713 & \\
\hline Rhipidothuria racovitzai & & MNHNP IE-2009-4932 & KX856797 & KX856729 & & KX874458 & & \\
\hline Sclerodactyla briareus & USA, Florida & SIO-BIC E6814 & KX856844 & KX856771 & KX874342 & KX874447 & KX856683 & KX856904 \\
\hline Sigmodota contorta & Antarctica & SIO-BIC E5135 & KX856863 & & & KX874474 & KX856720 & KX856871 \\
\hline Stichopus chloronotus & Mariana Islands, Guam & SIO-BIC E6843* & KX856818 & KX856755 & KX874352 & KX874424 & KX856701 & \\
\hline Stichopus vastus & Micronesia, Chuuk State & KSORC 0321 & KX856817 & KX856754 & KX874353 & KX874423 & & KX856886 \\
\hline Synallactes sp. & Mexico, Gulf of California & SIO-BIC E5607 & KX856803 & KX856749 & KX874365 & KX874420 & KX856680 & KX856888 \\
\hline Thelenota anax & Micronesia, Chuuk State & KSORC 0317 & KX856805 & KX856751 & KX874375 & KX874421 & KX856681 & KX856887 \\
\hline Thyone sp. & Papua New Guinea & FLMNH-IZC 14936 & KX856839 & KX856776 & KX874360 & & KX856696 & \\
\hline Thyonella gemmata & USA, Florida & SIO-BIC E6813 & KX856848 & KX856772 & KX874340 & KX874449 & KX856682 & KX856907 \\
\hline Ypsilothuria cf. bitentaculata & USA, California & SIO-BIC E4760 & KX856830 & KX856764 & KX874370 & KX874436 & KX856697 & \\
\hline Zygothuria oxysclera & France, Guiana & FLMNH-IZC 17117 & KX856825 & KX856735 & KX874393 & KX874430 & KX856709 & \\
\hline \multicolumn{9}{|l|}{ Outgroups } \\
\hline Patiria miniata & varies & varies & DQ060777 & DQ297074 & HM542106 & DQ676897 & AY370695 & DQ060004 \\
\hline Strongylocentrotus purpuratus & varies & varies & L28056 & $\mathrm{X} 12631$ & HM542410 & NM214544 & $\mathrm{X} 12631$ & XM790710 \\
\hline
\end{tabular}


Table 2. Node age constraints (minimum ages) used to estimate divergence times or stem lengths. All nodes were constrained as monophyletic. The 3-age dataset included nodes A-C. The 6-age dataset included nodes A-F.

\begin{tabular}{|c|c|c|c|c|}
\hline Node & $\begin{array}{l}\text { Median Age } \\
\text { Used }\end{array}$ & $\begin{array}{l}\text { 95\% Age Distribution } \\
\text { (Ma) }\end{array}$ & Node & Source \\
\hline $\bar{A}$ & 481 & $480-488$ & $\begin{array}{l}\text { Crown } \\
\text { Eleutherozoa }\end{array}$ & (Blake and Guensburg, 2005) \\
\hline B & 464 & $463-465$ & Crown Echinozoa & $\begin{array}{l}\text { (Lefebvre et al., 2013; Pisera, } \\
\text { 1994) }\end{array}$ \\
\hline $\mathbf{C}$ & 435 & $431-449$ & $\begin{array}{l}\text { Crown } \\
\text { Holothuroidea }\end{array}$ & (Reich, 2010a; Reich, 2015) \\
\hline D & 387 & $385-394$ & Stem Elasipodida & (Boczarowski, 2001) \\
\hline $\mathbf{E}$ & 246 & $244-257$ & Stem Holothuriidae & (Reich, 2004) \\
\hline $\mathbf{F}$ & 198 & 196-201 & Stem Molpadida & (Gilliland, 1992) \\
\hline
\end{tabular}




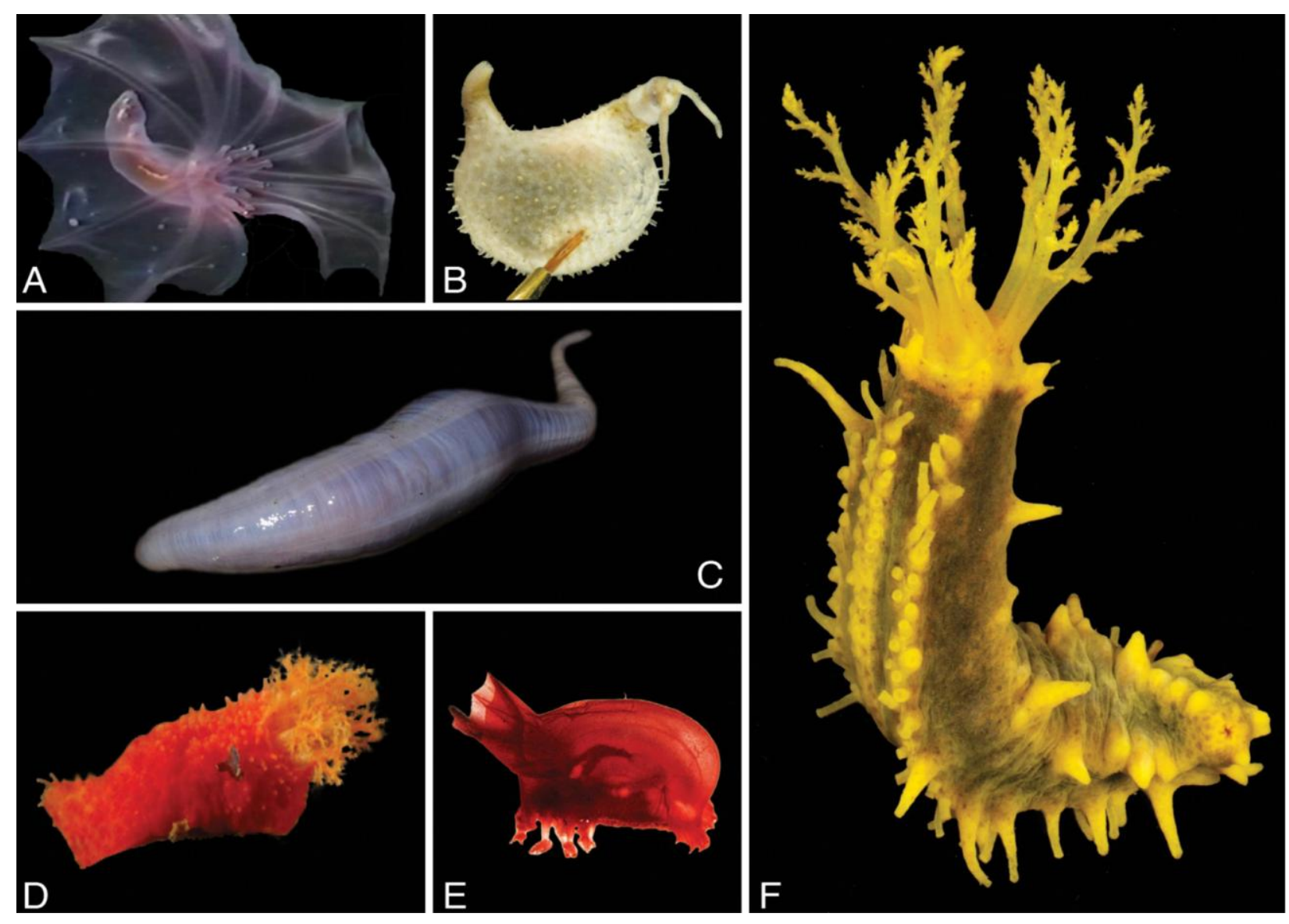




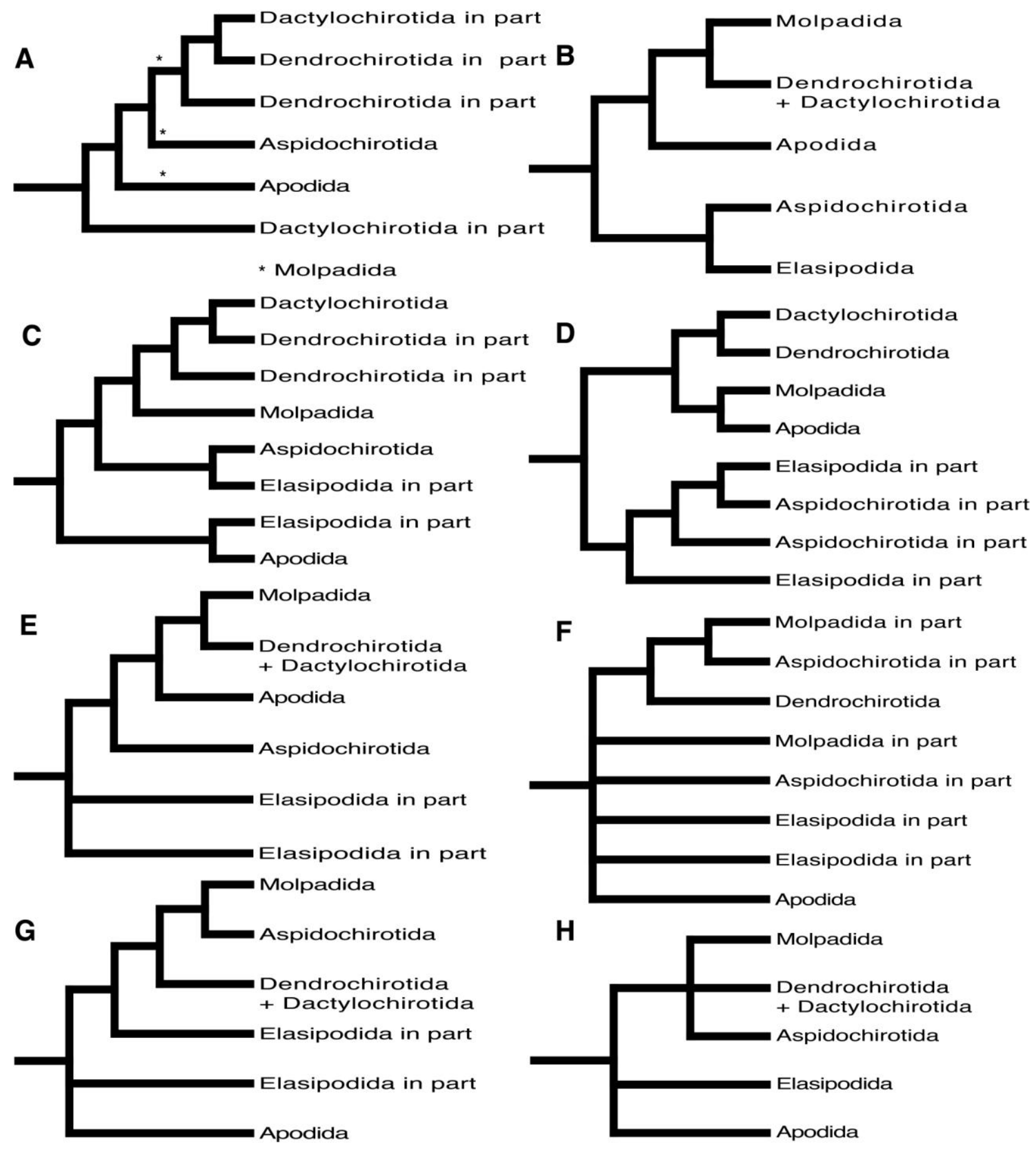



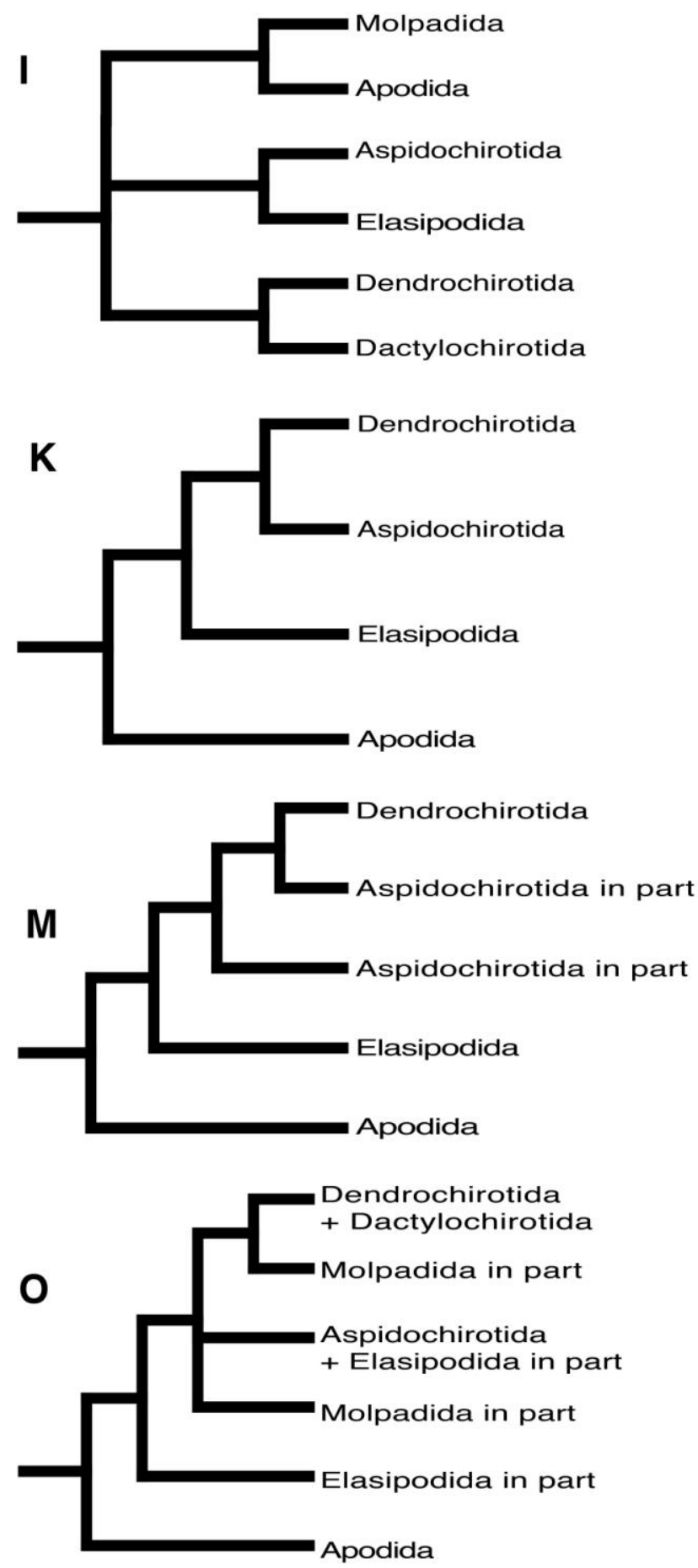

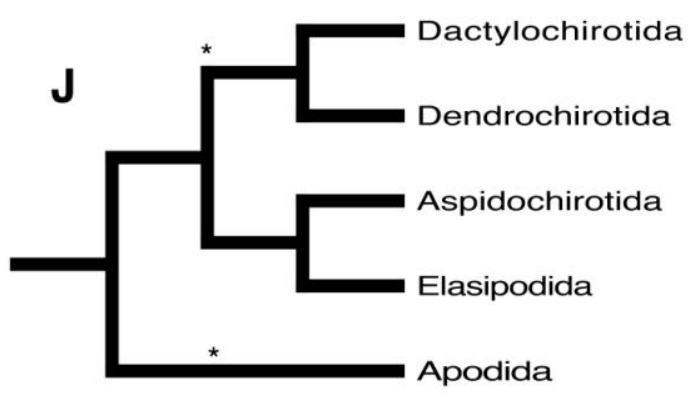

* Molpadida
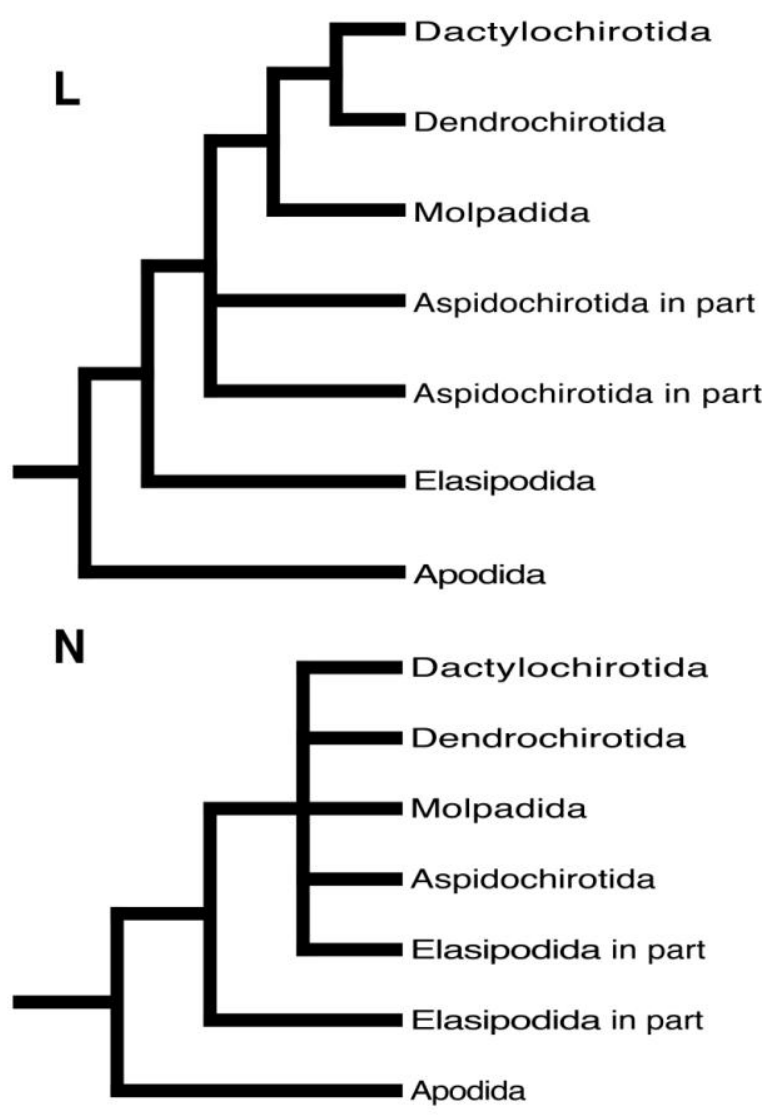


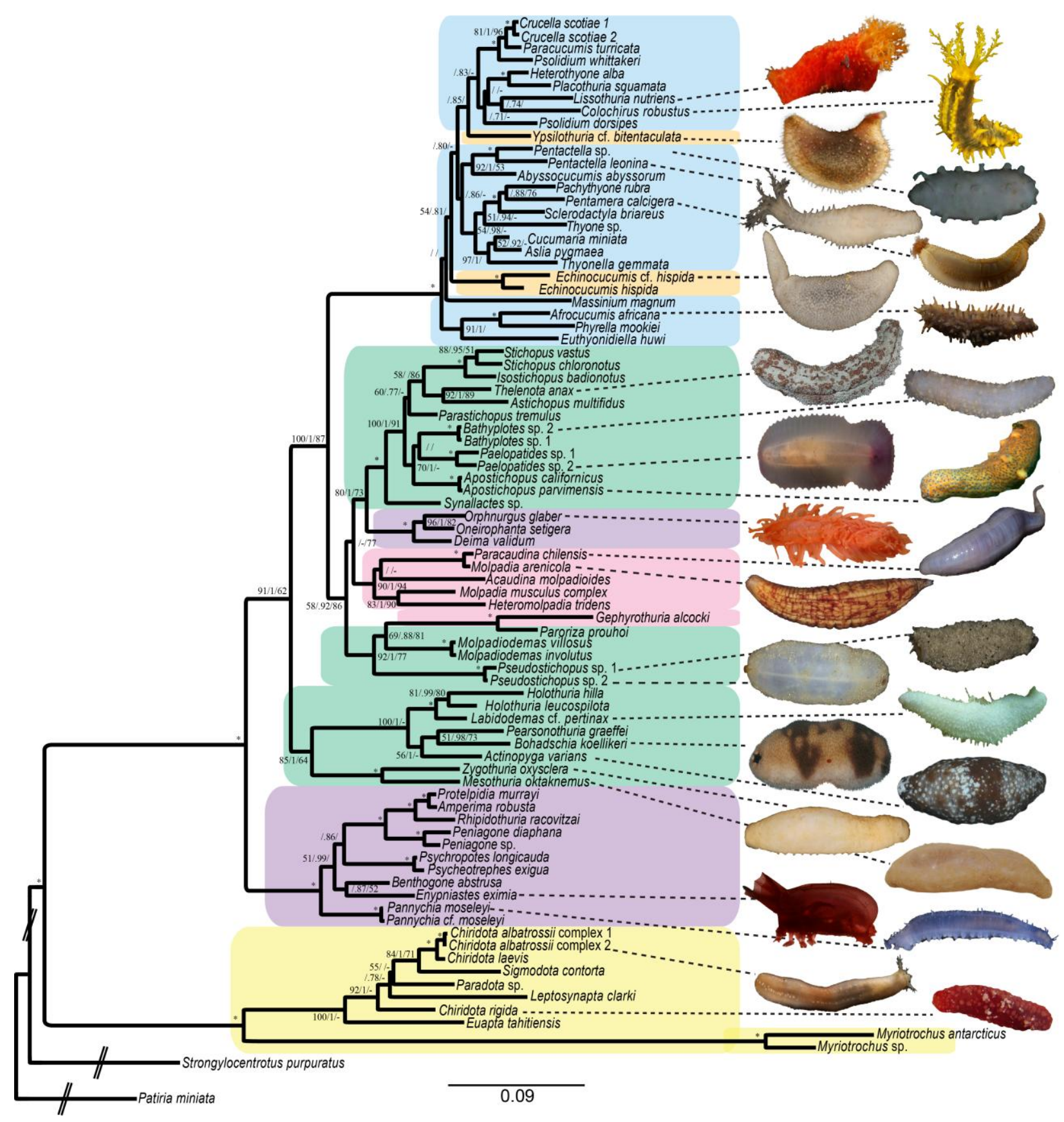




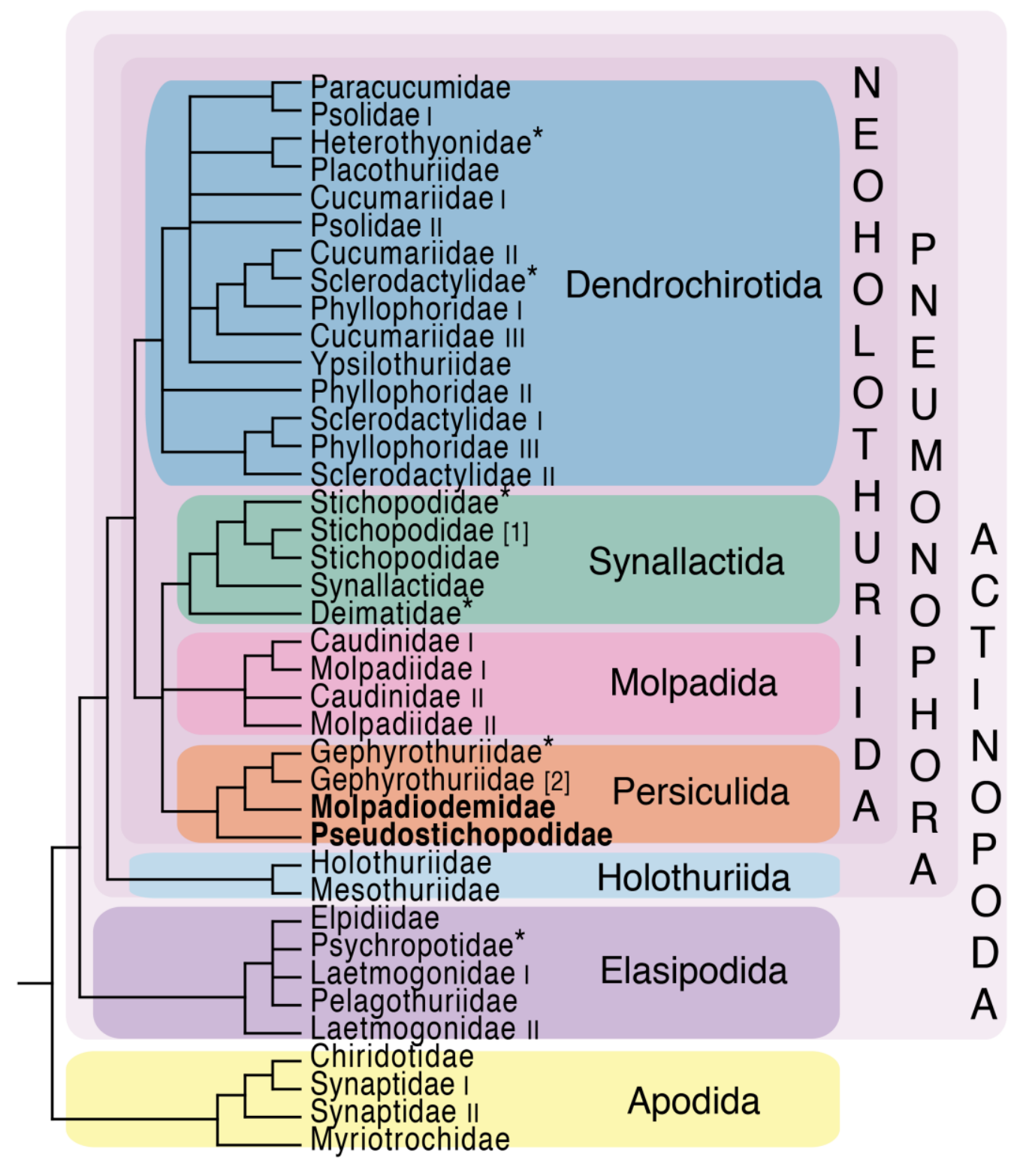




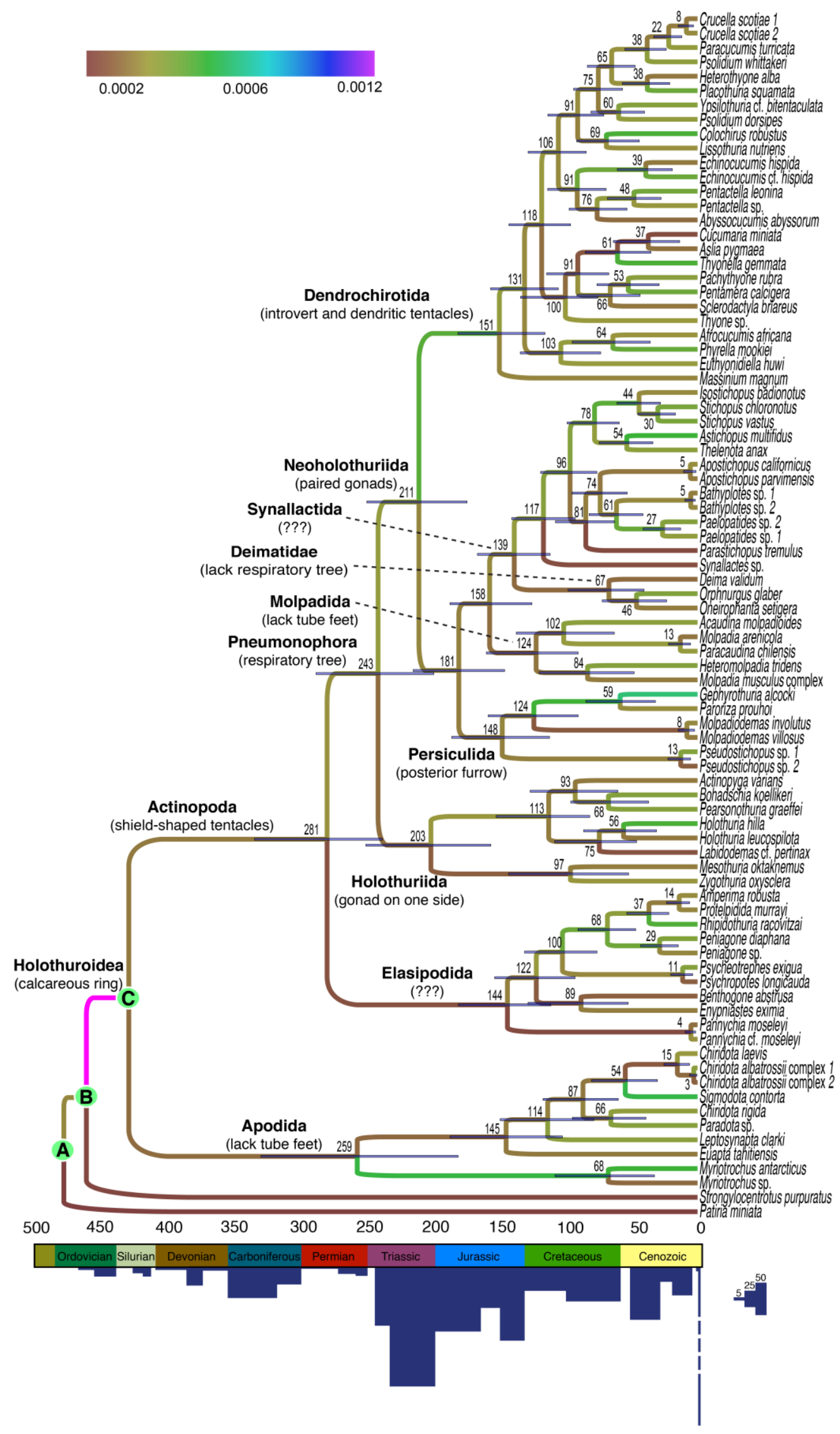




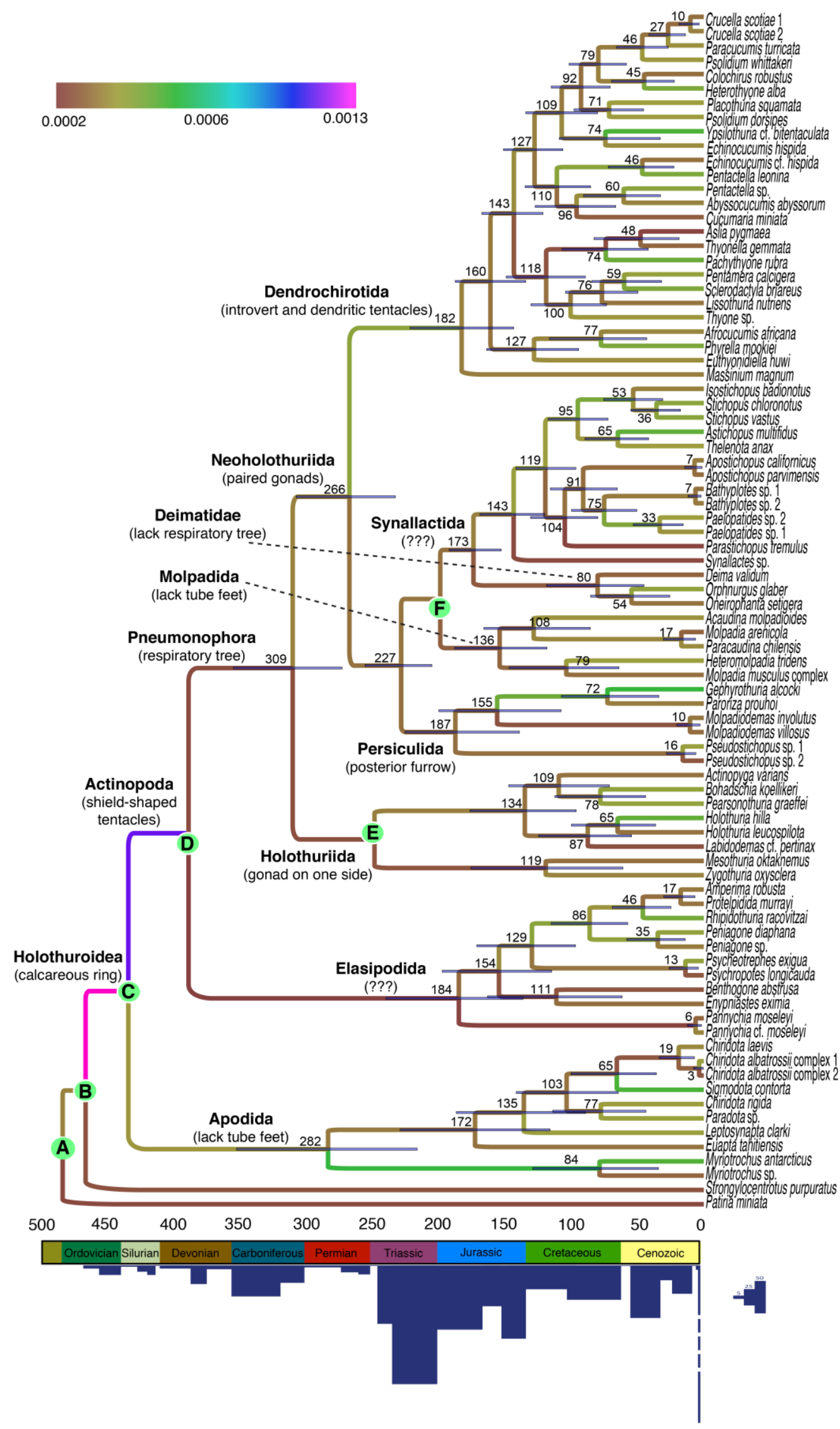




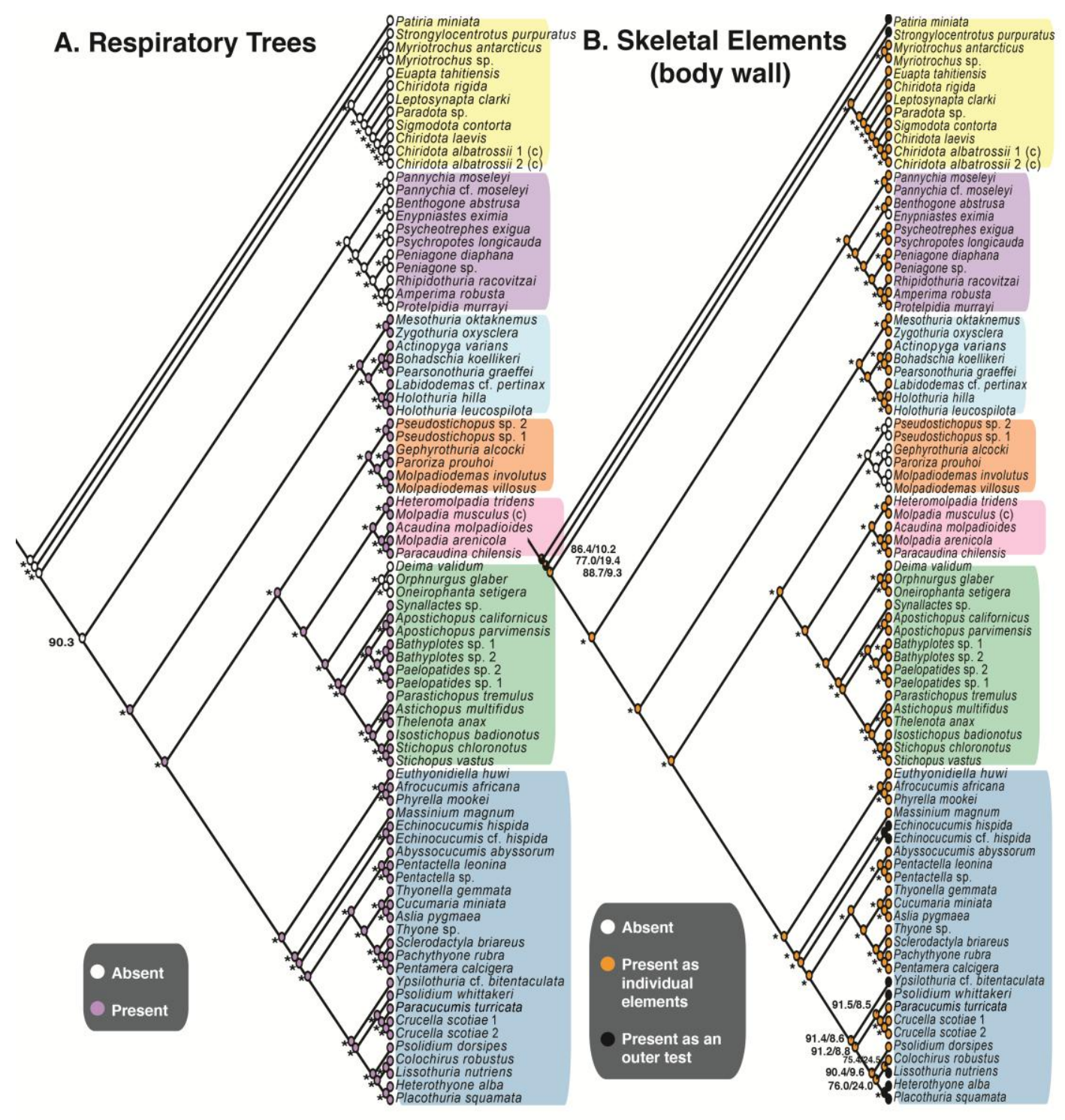

Maximum likelihood transformations for the respiratory tree $(A)$ and skeletal elements in body wall (B). Transformations were generated using the Mk1 model and the topology shown in Fig. XX. Estimated proportional likelihood values are displayed near nodes: an asterisk $\left(^{*}\right)$ indicates a node with an estimated proportional likelihood of $>95 \%$, and scores $<95 \%$ are listed in order of most likely states. Multiple scores are separated by a forward slash (/). Colors correspond to the clades seen in Fig XX. <- proposed nomenclature tree. 


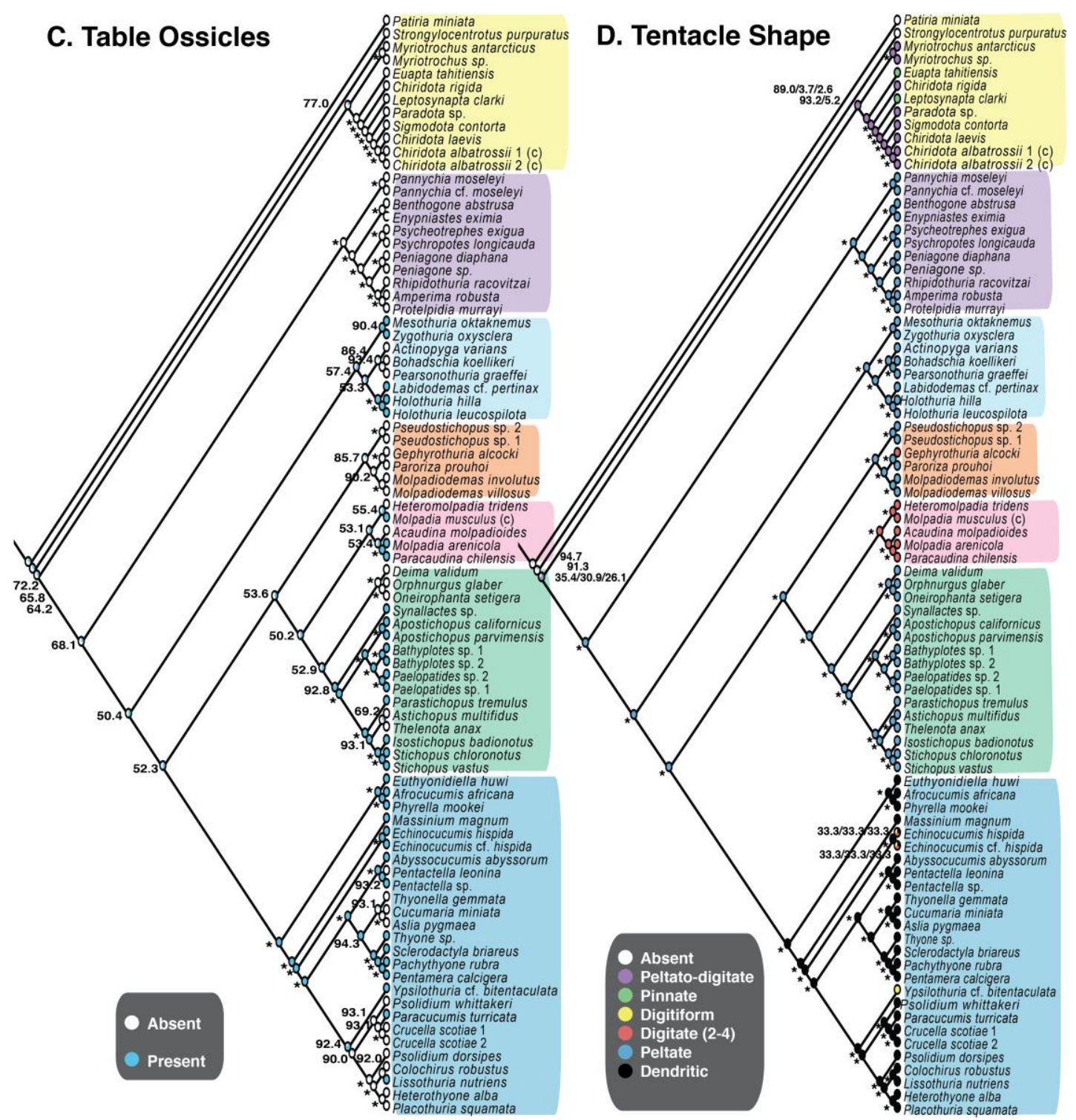

Maximum likelihood transformations for table ossicles (C) and tentacle shape (D).

Transformations were generated using the Mk1 model and the topology shown in Fig. XX. Estimated proportional likelihood values are displayed near nodes: an asterisk $\left(^{*}\right)$ indicates a node with an estimated proportional likelihood of $>95 \%$, and scores $<95 \%$ are listed in order of most likely states. Multiple scores are separated by a forward slash (/). Colors correspond to the clades seen in Fig XX. <- proposed nomenclature tree. 